\title{
PROCYCLICALITY OF FINANCIAL AND REAL SECTOR IN TRANSITION ECONOMIES
}

\author{
Mejra Festić*
}

\begin{abstract}
:
Financial sector is prone to cyclical movements and procyclicality of the financial system may endanger financial stability, which depends on asset prices and loan losses due to the fact that the deterioration of bank assets through non-performing loans is characteristics of banking distress. This was the case during Japan's lost decade and the Nordic banking crises. Even the classic banking panics of the Great Depression are being revised in the light of new evidence on the fundamental deterioration of bank assets.

Much empirical evidence supports the view that balance sheet variables, such as net worth affect investment and produce business cycle dynamics. In an upswing, the greater availability of credit leads to higher asset prices, which then serve as collateral for more borrowing.

Relatively unstable development of share prices on the capital market increases equity risk. This paper is based on the presumption that the stability of macro economic environment, less pronounced cyclical movements and insignificant procyclicality between GDP and equity (used as collaterals for credit insurance) lower equity risk. There was proved no significant procyclicality between collaterals and GDP according to low stock market capitalization. And due to the relation that equity risk (as a part of market risk) is determined by unstable development of shares prices, I accepted the hypothesis of low equity risk in the analysed transition economies on the basis of tested procyclicality.
\end{abstract}

Keywords: macro environment, collaterals, procyclicality, credit risk, equity risk, banking sector

JEL Classification: E31, E37, E61, G15

\section{Introduction}

Macroeconomic stability depends on the parameters governing inflation and output, meanwhile financial stability depends on asset prices and loan losses. Procyclicality refers to the tendency of the financial system to reinforce the business cycle.

\footnotetext{
*) Faculty of Economics and Business, University of Maribor, Razlagova 14, Maribor Slovenia (mejra.festic@uni-mb.si)
} 
Recent crises in emerging markets, globalization of financial markets, enhanced volatility of asset prices movements within industrialized and emerging economies and the fact that inflation is no longer an issue of great concern, lead us to the following questions: What are implications of asset market volatility for credit risk due to procyclicality? And what are specific implications for monetary policy?

Bernanke et al (1999) proved that the cost of borrowing depends on the financial position of bank commitments and values of collaterals they can provide. Bernanke and Gertler (1989) argue that a higher net worth has a positive effect on investment directly (Tobin's $q$ effects and the firms' balance sheet channel), because it increases the sources of internal finance, and indirectly because it reduces the external costs of financing, by offering more collateral (Kiyotaki and Moore 1997, Bernanke and Gertler 1995). Because equity has an important weight in the balance sheet position of firms, we can expose the relation between stock markets to the real economy and its correlation to procyclicality. Collapsing asset prices reduce the value of collateral that borrowers can use to secure loans and the ability to borrow. A fall in firm share prices may be signal declining future cash flows that are used for debt repayment and consequences could be downturn in aggregate real economic activity as well as banking distress. The asset prices contraction induces banking crises due to defaults on bank loans, which in turn induced a sharp contraction in bank capitalization.

\section{Historical Facts and Development Trends}

Over the last few decades, the global financial system has been subject to a variety of disruptive incidents (White, 2004); short-term price volatility in financial markets, often associated with a drying-up of market liquidity, losses due to rising operational risks in the financial sector, reflecting not only the decline of prudent governance during boom years, but also the increasing complexity of modern financial systems.

The most remarkable development in financial markets over the last few decades has been the prominence of credit and asset price booms, often associated with rapid rates of growth of real fixed investment. In the industrial countries, there was a sharp run-up in credit and asset prices, particularly equity and real estate, in the early 1970s. A second cycle began in the mid-1980s, which turned to bust in the early 1990s. Examples would include the banking crises in the Nordic countries and Japan in the late 1980s, the Mexican crisis of 1994 and the severe banking problems encountered in East Asia in 1997 and 1998.

The banking system in Japan suffered a short-lived capital crunch due to declines in asset prices and loan losses (Caprio and Klingebiel, 2003; Hoshi and Kashyap, 1999). The Nordic banking crises (1988-1993) suffered by Finland, Norway and Sweden followed a similar pattern. Systematic deregulation during the 1980s fuelled a credit boom (Berg, 1998, p. 197) and the Finnish savings banks, with a traditional concentration in real estate, had expanded faster than commercial banks during the boom and, as the downturn hit the real estate sector, they faced greater losses and contracted credit more than commercial banks (Vihriala 1997, pp. 40, 59, 90). The role of real estate was also apparent in Sweden (Englund 1999, p. 90). Hansen (2003) showed that bankruptcies were less related to the business cycle than 
to the 'financial cycle' in Nordic economies. The US Great Depression (1929-1933) witnessed the collapse of the financial system and a depression. Also the decline of bond prices is cited by Friedman and Schwartz (1963, pp. 355-356) as a major source of losses to banks. Falling prices produced debt-deflation (Fisher, 1933) where borrowers, attempting to reduce their indebtedness by distress selling assets, contributed to the contraction of money and credit producing further deflation.

Turning to persistent disinflationary forces with excess capacities in the 1990s, recognising that the maintenance of price stability has historically not been sufficient to ensure good domestic economic performance over time, monetary policy has reacted more to internal financial imbalances than it currently does. Trend growth is now more stable, cyclical fluctuations are now less pronounced and monetary policy has no longer to lean periodically against rising inflationary pressures.

The liberalisation of the global financial system and development of it is supported by technological progress, the growth of financial markets in recent years has been remarkable, as has the process of consolidation within the financial industry. These developments have sharply increased competitive pressures in the financial services industry and competitive pressures have led over time to changes in both financial structure and financial behaviour. These changes have also implied a marked increase in the variety of credit sources and, reductions in both the costs of financial services and the intermediation costs of credit. Such pressures, in turn, increase the incentives to engage in risky behaviour (Rajan, 2005).

\section{1 Risks in Banking}

In the course of their activities banks are confronted with (external and internal) risks regarding economic and institutional environment. The primary risks associated with banking activities are credit risk (defined as the risk of non-repayment of a loan), liquidity risk, market risk (including currency, interest rate, equity and commodity risk) and country risk.

Banks limit credit portfolio risk primarily by assessing in detail the financial situation of potential loan partners and collateral represents the main form of security, although the volume of credit derivatives has also grown recently (the risks attaching to financial derivatives are overwhelmingly market risks relating to the movements in market prices of their underlying assets, e.g. the capital market index, commodities, shares, other derivatives - Golin, 2005).

Market risk covers interest rate risk, foreign exchange risk, equity risk and commodity risk. The equity risk is a risk of securities falling in value that arises from developments on the capital market due to fluctuations of the financial results of issuers, economic expectations, changes in market interest rates and exchange rates and cyclical movements. With bonds the main risk is presented by interest rates, although currently this risk is not high owing to the relative stability of interest rates. A counter factor, however, is the relatively unstable development of share prices on the capital market, which increases equity risk.

Liquidity risk can be defined as the risk of banks not being able to fulfill their obligations in the required time and volume. In such cases the overall stability of the bank is of the utmost importance to have a sufficient volume of quick assets (tradable bills on the short-term bond market at very short notice) that correspond 
to the size of the bank and may be used to cover any unforeseen outflows of funds. And country risk is linked with the changes, primarily political, legislative as well economic downturn that might prevent clients and business partners in the relevant country from repaying their liabilities in volume and time.

\section{2 Macroeconomic Environment and Procyclicality of Credit Risks}

Credit risks and measuring of financial stability include a wider range of indicators - micro and macro (Davis, 1999; Fry, 1997). First, there is a need for flow-of-funds data in order to track overall patterns of corporate and household sector gross indebtness, relative to income/GDP or gross financial or total assets. In this context, information on investment patterns of institutional investors, the balance between sources of corporate debt finance in banking and bond markets and maturity of debt may be helpful. Second, various financial prices may give valuable direct indicators of the degree of risk perceived by markets. Third, monetary data, together with inflation and nominal GDP projections, are needed in order to assess whether growth in a broad monetary aggregates is rapid or low or negative; velocity includes additional information on financial innovation and liberalisation. Fourth, detailed data on banks and other financial institutions, on their competitive position are needed. Fifth, qualitative data on easing financial regulation that could provoke high-risk behaviour are required. Finally, complementing financial data and overall macroeconomic data are required in order to assess the current state of cycle. Inflation gives evidence on the ease and tightness of monetary policy, real GDP gives the evidence on whether the cycle is sufficiently long-standing, and stock prices give evidence on cycle movements and potential downturns.

Macroeconomic considerations should be integrated into risk measurement, particularly during the upswing of business cycles. A higher level of economic growth leads to higher values of potential collaterals, thereby loosening credit constraints and making debt financing easier. If the expansion is associated with rapid credit growth, large increases of asset prices, high level of investment and excessive capital accumulation, the level of credit risk is higher. A strong economic expansion can increase the likehood of an economic downturn. Accordingly, periods of strong economic growth might, under some circumstances, be characterised by an above the average level of credit risks. Average credit risks increase around a peak of the business cycle, and perhaps a reduction in credit risk around the trough of the cycle, given the imminent recovery. Risk is built up in a boom but materialises in the downturn (see Frye, 2000).

We cannot accept the presumption that because the expansion has gone, credit risk has increased, while GDP is a unit root process, which means that most development in GDP can be viewed as permanent, rather than as a temporary fluctuations around a trend. A decline in credit risks comes when macroeconomic conditions are strong - on the assumptions that strong conditions are likely to continue and that the economy's current performance can be taken as the best guess of its future performance (Borio et al, 2001). In this case the boom does not mean that a recession is imminent and a recession does not mean that a recovery is likely. There appears to be a little empirical support for this proposition, but the longer the expan- 
sion runs the greater the likehood of an economic downturn (Amato and Furfine, 2003).

Borio, Furfine and Lowe (2001) document the extent to which financial systems are "inherently procyclical"; that is, perceptions of value and risk move up and down with the economy as does the willingness to take risks in order to keep health financial system. This tendency can be seen clearly in a large number of financial measures: credit spreads, asset prices, internal bank risk ratings, and such accounting measures of expected losses as loan loss provisions, etc.

Measuring of the range of possible outcomes can be taken as having a number of common building blocks, which include: a system of rating loans, assumptions about the correlation of default probabilities across borrowers, assumptions about the loss incurred in the case of default and assumptions regarding the correlation between the default probabilities and loss given default (Crouhy et al, 2000, Gordy, 2000, Lopez, 2002). Market-based rating systems rely on measuring probabilities of default from equity prices, which is a decreasing function of firms equity prices and an increasing function of the volatility of equity prices. If the market generally expects a deterioration in the macroeconomy, and as a result stock prices decline, implied probability of default (PD) would rise even if current economic conditions remained robust. If the uncertainty level in the financial system increases, which leads to volatility of equity market, PDs would rise. If equity prices are overvalued, calculated PDs are likely to underestimate true probabilities, and perhaps suggest a relatively low level of risk (Jordan et al, 2002, Saunders and Allen, 2003, Bangia et al, 2002).

\section{3 Equilibrium Equity Prices, Procyclicality and Monetary Policy}

Borio and Lowe (2002) look at factors driving probability of financial stress (PFS) and demonstrate that financial crises have generally been preceded by a combination of growth in credit and asset prices. Moreover, this procyclicality then interacts with the real economy in ways that can amplify economic fluctuations (Goetz 2004). Falling asset values can impair borrowers' balance sheets to the point of interrupting the intermediation of credit, which in turn exacerbates macroeconomic conditions. The effect of falling asset prices ('wealth effects') is indirect and involves feedback from the banking system in the form of a credit contraction. The resulting wealth effect reduces consumption spending, and the price level falls. Falling prices in the presence of fixed nominal debt may cause widespread default among firms and firms suffer an unexpected loss on assets sold. If so, the banking system faces loan losses which, if large, reduce bank capital. A binding capital constraint generates feedback from the banking system: the contraction of credit in turn depresses asset prices, and drives up the bank loan rate. When borrowers repay, the effect 'passes through' the bank balance sheet; once borrowers default, asset prices drive bank capital, and constrained credit in turn drives asset prices (Bernanke, 1983; Mishkin, 1999; Calomiris, 1995; Chen, 2001). This interaction can explain capital crunches, financial instability, and banking crises, either as fundamental or as selffulfilling outcomes (Diamond and Dybvig, 1983; Diamond and Rajan, 2001).

We can mention equilibrium equity prices theory in this context. Brennan and Xia (2001) have developed a dynamic equilibrium model with an element of lear- 
ning to match the stock price volatility and the equity premium. The non-observability of the growth rate of dividends introduces an element of learning into the stock valuation process which is shown to increase the volatility of the stock price and therefore reduce the level of risk aversion required to explain the equity premium (Timmerman, 1996). Grossman and Shiller (1981) have argued that stock returns appear to be too volatile given the smooth process for dividends and consumption growth. Mehra and Prescott (1985) claim that this smoothness in consumption and dividend growth gives rise to an "equity premium paradox" since it makes it impossible to explain the equity risk premium with a risk aversion parameter.

The explanation for rising stock prices with increasing estimation risk stems from the precautionary savings. The precautionary savings motive drives down longterm interest rates in response to increased uncertainty about future consumption (Brennan and Xia, 2001) and an increase in the uncertainty will raise the bond prices as well as the expected future dividends. In the equilibrium, however, the precautionary savings effect dominates the risk aversion effect.

Abel (1988), Barsky (1989), Barsky and De Long (1993) discuss the co-movement of stock and bond prices due to the change in the variance of dividend stream, and in the expected dividend growth rate. In particular, when an expected future recession is coupled with a high degree of estimation uncertainty, the expected return for short horizons can be negative. Hong (2001) developed a dynamic equilibrium model about the impact of estimation uncertainty on the expected returns and equity premiums over different holding horizons. The model implies low expected returns around the peaks of economic expansion and high expected returns in the depths of economic contraction. Consequently, the stock price is higher with greater uncertainty and the equity premium over short horizons is actually reduced.

Veronesi (2000) shows in a model of unobservable regime shifts that imprecise signals about the current state of the economy tend to increase the stock price and reduce the equity premium; agents' information set includes not only the realized dividend process, but also an additional noisy signal process and the existence of different signal process alters the market price of risk. Gertlei and Aiyagari (1999) explained the overreaction of asset prices to movements in short-term interest rates, dividends, and asset supplies; and specialized traders must satisfy margin requirements that lead to enhanced volatility of prices. When some shock pushes asset prices to a low enough level at which the margin constraint binds, traders are forced to liquidate assets.

Mishkin and White's (2003) general point is that monetary policy should react to the threat of financial instability, not to the level of asset prices per se. When the argument is cast in the form of interest rate rules, this policy would be captured by a flexible threshold term, not by the systematic reaction to asset prices examined by Bernanke and Gertler (1999) and Cecchetti et al (2000). In low inflation environment a central bank has the flexibility to ease policy to avert a crisis but in an open economy reducing interest rates also depreciates the currency, which weakens borrowers financial position to the extent that they have liabilities in foreign currency. The central bank might not react on asset prices movements according to Gertler et al (1998, p. 8) because there is endogeneity between exchange rate and real economy and this relation produces potential undesired effects. The fact is that a rise in productivity growth trend can support a higher growth rate on equity; and 
central bank should pay attention to risk exposure of private financial institutions and non-financial borrowers according to Basel standards (BIS 2004).

\section{3. 1 The Role of Regulatory Framework in Macro Environment}

A first guiding principle for a macro-financial framework would be that both regulatory and monetary policies should be applied more symmetrically over the cycle. Examples of the former might be seen in the recent behaviour of a number of central banks that might have been risen policy rates in the face of rising asset prices (White, 2006). The two-pillar approach of the ECB could also be noted, moreover the suggestion here would be to use the monetary pillar to resist financial excesses in general rather than inflationary pressures in particular (Issing, 2005). Not only that this would help restrain credit excesses, but it would also allow capital to be run down in bad times to cushion the economy from associated credit constraints.

A microprudential standards are designed to improve the soundness of financial institutions, financial markets, and the underlying legal and payments infrastructure. Given the growing importance of markets, both to provide financing and to transfer risks, market monitoring and the evaluation of structural developments affecting markets would have to be further enhanced (like cash reserve ratios, liquidity ratios, loan-to-value ratios, risk weights for regulatory capital, collateral requirements, etc.). Goodhart and Danielsson (2001) suggest relating prudential norms to the rate of growth of loans or asset prices, margin requirements and repayment periods could all be tightened to enforce more prudent behaviour. These prudential norms could affect the pricing of risk, provisions for losses (for expected losses) or the accumulation of capital (for unexpected losses).

The benefits of the stable macroeconomic environment, less pronounced cyclical movements and stable monetary policy are not sufficient for stable financial and banking system nowadays. What is being suggested here is that financial imbalances, both domestic and international, need more systematic attention, and that this might be accomplished through an evolutionary adaptation of the current policy framework. As to the risks, new capital adequacy framework is based on the setting of capital requirements in relation to the extent of banking activities and their degree of risk in order to cover unforeseen losses from banking operations. There are strong arguments that capital should be built up in good times, so that when bad times come, a sufficient buffer exists so that losses can be absorbed without ruining the solvency of banks or more generally, without the stability of financial system (BIS, 2004; ECB, 2001).

\section{Macroeconomic Environment in Transition Economies}

New EU Member States have been through similar structural changes and they share common structural characteristics. Banking sector in New Member States have operated under favourable conditions owing to GDP growth which outstripped that of the EU-15, considerable progress in real and nominal convergence. Lowering inflation and interest rate differential lead to a more compatible macro environment within the euro area. The non-cyclical changes in the government budget balance could reflect either a lasting structural change or the effect of temporary measures. 
Making the tax/benefit system more employment friendly (for Slovenia see Hauptman, 2004; pp. 61-83) through strengthening work incentives could make a significant contribution to fiscal consolidation while promoting economic growth and real income convergence in the context of completing the process of transition to a market economy (European Commission 2004, 2004a, 2005).

Table 1

\section{Convergence Criteria in Transition Economies for $2005 / 2006^{\mathrm{e}, \mathrm{f}}$}

\begin{tabular}{|l|c|c|c|c|}
\hline & $\begin{array}{c}\text { public debt }^{\mathrm{e}} \\
(\% \mathrm{GDP})^{\mathrm{a}}\end{array}$ & $\begin{array}{c}\text { fiscal deficit }^{\mathrm{e}} \\
(\% \mathrm{GDP})^{\mathrm{b}}\end{array}$ & $\begin{array}{c}\text { inflation }^{\mathrm{e}} \\
(\%)^{\mathrm{c}}\end{array}$ & $\begin{array}{c}\text { interest rate } \\
(\%)^{\mathrm{d}}\end{array}$ \\
\hline Slovenia & 29.5 & -1.9 & 2.5 & 3.8 \\
\hline Czech Republic & 36.6 & -3.7 & 2.9 & 3.5 \\
\hline Hungary & 58.0 & -6.7 & 3.0 & 6.4 \\
\hline Lithuania & 20.2 & -1.8 & 2.8 & 3.7 \\
\hline Poland & 47.0 & -3.6 & 2.3 & 5.2 \\
\hline Slovakia & 38.2 & -3.0 & 3.6 & 3.5 \\
\hline EU -25 & 64.2 & -2.7 & 2.2 & $3.3^{\mathrm{f}}$ \\
\hline
\end{tabular}

${ }^{\text {a }}$ General government debt as \% of GDP; ${ }^{b}$ Public balance as \% of GDP; ${ }^{c}$ Harmonized indices of consumer prices (HICP); ${ }^{\mathrm{d} N o m i n a l ~ l o n g-t e r m ~ i n t e r e s t ~ r a t e s ~ f o r ~ 2005 ; ~ t h e ~ v a r i a b i l i t y ~ o f ~ d o m e s t i c ~}$ inflation rates and the country risk premium are the main factors affecting high nominal long-term interest rates; ${ }^{\mathrm{f}}$ euro area, e estimation; ${ }^{\mathrm{f}}$ In continental Europe, both corporate and government debt levels as of mid-2005 remained very high. About Stability and Growth Pact see, Rostowski (2005, pp. 185-198); about exchange rates in New EU Member States, see Boršič (2005, pp. 9-14).

Source: European Commission 2005, Autumn 2005 forecast for 2006

In Lithuania, high productivity growth, structural reforms, acceptable wage growth and effective appreciation pressure of litas contributed to lowering of inflation rate with a relatively strong GDP growth. Following the impact of Russian crisis on Lithuanian export sector, real GDP growth turned to be negative in 1999. Inflation rate increased in 2005 due to tax accommodation to the EU standards and higher administered prices. Upside risk to inflation is associated with a possible overheating of the economy and strong credit growth. Narrowing interest rate differentials with the euro area benefited from positive development of Lithuanian economy. Public debt ratio rose in the 1990s due to higher capital expenditures and higher compensation for employees and social contributions.

In the Czech Republic, interest rates exhibited a relatively high degree of volatility due to public finance uncertainties and a strong decline of capital inflows due to the fact that Czech Republic was successful in attracting foreign direct and portfolio investment, which resulted in higher GDP growth in late 90s. Inflation started to pick up again in 2001, although this upward trend was soon reversed by lower import prices, falling food prices and strong retail competition. Oil prices, indirect taxation and administered prices have also contributed to inflation volatility. Upside risks for inflation are mainly related to the uncertainty associated with the ef- 
fects of indirect tax changes and the adjustment of administered prices. The main factors underlying a development of interest rates was increasing inflation differential between the Czech Republic and the euro area as well as uncertainty of fiscal policy implementation. The $C z e c h$ authorities adopted a system of binding mediumterm nominal expenditure ceilings for central government.

The continuation of relatively high inflation development in Slovakia was largely due to upward adjustment of indirect taxes and administered prices as well as oil price. The anticipated reduction of inflation in 2005 is mainly a result of the completion of adjustments in administered prices and indirect taxes, as well as moderation of wage increases, fiscal consolidation and implementation of structural reforms. The introduction of flat rates for income tax, corporation tax and value-added tax at the beginning of 2004 provided a further stimulus to the inflows of foreign direct investment. Interest rates proved to be stable with a declining trend partially due to stable exchange rate and fiscal consolidation. The fiscal deficit is mainly related to the tax reform and problems connected with health and pension system reforms. A debt repayment from privatization revenues lowered the debt ratio and structural reforms with regard to social security contributions that could make a significant contribution to fiscal consolidation.

In Slovenia, a disinflation process has been supported by fiscal policy, structural reforms, including the de-indexation of financial contracts and wages, as well by progressive liberalization of financial markets (Oplotnik 2003, pp. 211-216). Inflation was influenced also by fast administered prices growth and oil price increases. Interest rate differential against EURIBOR has been declining. In Slovenia, consolidation led to a significant lowering of debt in the mid-nineties, also due to reduced expectation that deficits would be monetized.

In Hungary, moderation of inflation was supported by structural and wage policies in parallel with a relatively strong real GDP growth. GDP growth slowed down in 1996 and again between 2001 and 2003. The increase of inflation in 2004 was a result of temporary factors, like the rise in value-added tax and other indirect taxes, lagged effect of depreciation and oil prices. The reduction in fiscal deficit is expected by decreasing expenditures in the areas of public sector wages, pensions, health related spending, social benefits, subsidies and a favorable economic growth. Government introduced a number of measures concerning structural reforms, lowering of employment in public sector and rationalization of public finances as well as postponing of some public investment. Long-term interest rates showed a downward trend reflecting a declining inflation and improving global performance on emerging markets.

In Poland, a reduction of inflation was achieved as a result of administered prices accommodation, adequate wage growth in parallel with strong real GDP growth that decelerated at the end of 2000, when economy started to recover gradually from the end of 2002 due to foreign direct investment. Interest rates followed a downward trend from mid-2001 to mid-2003, reflecting a significant decline in inflation rate. Growing fiscal uncertainty (the fiscal deficit is mainly related to the tax reform and problems connected with health and pension system reforms), inflationary pressure, depreciation, uncertainty about economic and financial developments were reflected in higher interest rate differential between Poland and the euro area. 
Table 2

Country Rating and Banking Sector Indicators for 2004

\begin{tabular}{|c|c|c|c|c|c|c|c|c|c|c|}
\hline & Fitch & Moody's & $\begin{array}{c}\text { Standard } \\
\text { and } \\
\text { Poor's }\end{array}$ & $\begin{array}{c}\text { bank rate } \\
\mathrm{M} / \mathrm{S} \& \mathrm{P}\end{array}$ & $\begin{array}{c}\text { asset quality } \\
\text { (NPL as \% } \\
\text { of total } \\
\text { loans) }\end{array}$ & $\mathrm{C} / \mathrm{I}^{\mathrm{c}}$ & $\begin{array}{c}\mathrm{RoA} / \\
\mathrm{RoE}^{\mathrm{d}} \\
(\%)\end{array}$ & \begin{tabular}{|c|} 
Capital \\
adequacy $^{\mathrm{e}}$
\end{tabular} & $\begin{array}{l}\text { EBRD } \\
\text { index of } \\
\text { banking } \\
\text { sector } \\
\text { reform }^{* *}\end{array}$ & $\begin{array}{c}\text { Stock } \\
\text { market } \\
\text { capitalization } \\
(\% \text { of GDP })^{\mathrm{g}}\end{array}$ \\
\hline $\begin{array}{l}\text { Czech } \\
\text { Republic }\end{array}$ & A- & $\mathrm{A} 1$ & A- & $2-/ 2+/ 2-$ & 4.3 & 52.3 & $1.4 / 25.3$ & 11.9 & 4.0 & 32 \\
\hline Hungary & A- & $\mathrm{A} 1$ & A- & $2-12+/ 2-$ & 2.1 & 60.6 & $2.5 / 25.2^{*}$ & 11.4 & 3.7 & 35 \\
\hline Poland & $\mathrm{BBB}+$ & A2 & $\mathrm{BBB}+$ & $3 / 2 / 3$ & 5.7 & 68.0 & $1.5 / 18.7$ & 15.4 & 3.3 & 30 \\
\hline Slovenia & AA- & $\mathrm{Aa} 3$ & AA- & 1-/1-/1- & $5.5^{*}$ & 62.5 & $1.1 / 10.0$ & $11.8^{*}$ & 3.3 & 23 \\
\hline Slovakia & A- & A3 & A- & $2-12-12-$ & 2.0 & 70.7 & $0.9 / 15.0$ & 15.9 & 3.3 & 10 \\
\hline Lithuania & A- & A3 & A- & $2-12-12-$ & 2.5 & 77.7 & $1.1 / 13.6$ & 10.9 & 3.0 & 14 \\
\hline
\end{tabular}

${ }^{a}$ country rating (foreign currency - long run) for December 2004; ${ }^{b}$ definitions of non-performing loans and other doubtful loans differ between countries; data for 2005 and for Slovenia for 2004, IMF (2006); ${ }^{\mathrm{c}}$ cost/income ratio for commercial banks for 2003, ECB (2005); ${ }^{\mathrm{d}}$ return on assets, return on equity for 2005, IMF (2006); ${ }^{\text {e }}$ solvency ratio for 2005; for Slovenia 2004, IMF (2006);

${ }^{f}$ The ERBD indicators (for 2003) of banking sector reform are measured on the scale from 1 to $4+$ : score 2: established internal currency convertibility, significant liberalised interest rates and credit allocation; score 3: achieved substantial progress in establishing prudential regulation and supervision framework; score 4: level of reform approximates the BIS institutional standards; ${ }^{\mathrm{g}}$ 03Q/2005; * 2004; ** 2003

Source: ECB 2005, pp. 10, 16, 32-40, 41, Moody's 2005 and IMF (2006), Ihttp://dsbb.imf.org/ statistical/appendixl

The EBRD indicators show that the capacity for effective prudential regulation and supervision has been developed (including procedures for the resolution of bank insolvencies), budget constraints on banks have been hardered by eliminating preferential access to concesionary refinancing by the central bank and in this way stringent capital adequacy norms have been applied in New Member States (NMSs). Reduced restriction in banking, removal of barriers, increasing competitiveness (for Slovenia see Beloglavec, 2004, pp. 35-77; Mlinarič, 2000, pp. 15-37), prudent regulations, the possibility of banks to engage in a wider range of financial activities, etc. show the trend of catching-up with BIS standards and loan to asset ratio is catching-up relatively rapidly with the EU-15 as well (ECB, 2005). Foreign bank lending and inter-company loans play a significant role in the financing of non-financial enterprises in most NMSs. The proportion of foreign debt (i.e. foreign bank loans + intercompany loans + trade credit) is even higher than $50 \%$ of total corporate debt. Concentration and net margins are negatively correlated, while narrowing margins increase the need to improve cost efficiency. There is a positive correlation between foreign ownership and banking sector performance (ECB, 2005, pp. 19-21). But RoA may vary substantially within different NMSs not depending only on ownership but also on the specialization and strategy of individual banks. Foreign 
ownership is beneficial for the banking sector of NMSs since it involves a transfer of technology and human capital, which increases the operational capacity of local banks and improves $\mathrm{C} / \mathrm{I}$ ratio. In particular, foreign ownership is believed to have contributed to an improvement of risk profile and hence to financial stability in NMSs. While favourable macroeconomic environment has generally been conducive to banking sector stability, and has also improved RoA and C/I ratio, some problem areas remain where further improvements are needed (Weill, 2005; BIS, 2005).

The level of financial intermediation is still low but increasing, the private sector in NMSs relies 2.5 times more on bank finance than on stock market financing, the structure of banking sector is dominated by commercial banks, direct market finance has a low share, lending is growing rapidly (but despite high lending growth recently banks maintained adequate solvency buffers) and customer deposits are the most important funding source for banks. Despite the improving trends in the quality of assets in NMSs, the share of non-performing loans (NPL) and other doubtful loans is still considerably higher than in the EU-15 (IMF 2006, p. 188). ${ }^{1)}$

The substantial increases in equity prices in the NMSs may have reflected a rise in the fundamental values of the shares. In terms of amounts outstanding, shares and other equity are an important source of financing for non-financial corporations in NMSs.

\section{Empirical Analysis}

According to the facts that the relatively unstable development of share prices on the capital market increases equity risk, that higher volatility of equity market increases probability of default, that market- based rating systems rely on measuring probabilities of default from equity prices, which is a decreasing function of firms equity prices and an increasing function of the volatility of equity prices, the fact that cyclical movements are less pronounced nowadays and the fact that economies with poorer credit ratings are likely to be more sensitive to cyclical fluctuations, we tested the procyclicality between shares' value (i.e. potencial collaterals) and GDP movements. Evidence suggests that the strong procyclicality of collaterals may cause higher potential financial instability. Second, shares' value could be high because of strong demand for them induced by low global policy rates; and higher shares' values (potentially eligible for credit insurance) induce an increase of credit volume. In this context we tested the shares' value movements explained by interest rate movements when considering that interest rates have a trend of lowering due to competitiveness in financial sector and due to Maastricht convergence criteria. Third, rapid credit growth, large increases of asset prices, high level of investment and excessive capital accumulation increase the level of credit risk. The explanation for rising stock prices with increasing estimation risk could stem from the precautionary savings. The precautionary savings motive drives down long-term interest rates and an increase in the uncertainty will raise the prices of shares as well as the expected future dividends. And in this context we tested the relation between

1) There are differences in NPL classification (ECB, 2005, pp. 22-25). 
savings and share prices. On the basis of these hypotheses we concluded on potential treat of financial stress in transition economies.

\section{1 Empirical Analysis - Specification of Used Data and Methodology}

The monthly time series expressed as annual percentage change were used for the period from 1996 to 2004 for Hungary, Poland, Slovakia, Slovenia, Lithunia and the Czech Republic. ${ }^{2)}$ For GDP, public debt and unemployment we have interpolated quarterly data into monthly data (we used constant interpolation method, constant with average matched to the source data) for transforming low (quarterly) frequency into higher (monthly) frequency data). The Program Eviews 4.0 was used.

The key issue in economic modelling is whether the time series under investigation are non-stationary or stationary around a deterministic trend or difference stationary (Dickey and Fuller, 1979, pp. 427-431; Fuller, 1976, pp. 78-81). A trend stationary time series have a deterministic trend, whereas a difference stationary time series have a variable, or stochastic, trend (Hamilton, 1994, pp. 53-69; Sargent, 1981, pp. 213-248; Eichenbaum, 1992, pp. 310-331). Stationarity of the used time series were obtained by the $\log (\ln )$ function. The time series were normalized by average value and standard deviation $\left[\left(\mathrm{X}_{\mathrm{t}}-\right.\right.$ average $) / \mathrm{St}$.dev $]$. The obtained standard deviation is 1.00 , with the obtained average being 0.00 for all time series.

We needed to decide which explanatory economic variable to include in the regression functions because of the fact that macro-economic variables $\left(\mathrm{z}_{\mathrm{i}, \mathrm{j}}\right)$ could be correlated, reducing the size of the linearly independent set of variables. Correlation between the variables could be calculated on the basis of the following equation (Wall et al, 2003, pp. 22-24, Eviews 4.0, p. 213):

$$
\rho=\left(\Delta z_{i}, \Delta z_{j}\right)=\rho_{\text {factor }}(i, j)=\frac{E[\Delta z i(t) \cdot \Delta z j(t) \mp E[\Delta z i(t)] \cdot E[\Delta z j(t)]]}{\sigma \Delta z i \cdot \sigma \Delta z j}
$$

On the basis of correlation matrix, covariance matrix and contribution of eigenvalues to the explained variance we chose the time series, which were estimated to be relevant as macroeconomic variables, which have maximal explanation level of collaterals' value and which explain the residual factors of endogenous variable movements.

We used time series of monthly stock exchange index, gross savings as $\%$ of GDP, public debt as \% of GDP, short-term 3 months (real) interest rate, GDP growth rate, net export, unemployment, inflation (HCPI) and GDP deflator. We excluded

2) Data available on: http://dsbb.imf.org/Applications/web/sddsnsdppage

http://www.cnb.cz/en/statistics/sdds/

http://www.lbank.lt/Eng/Statistics/nsdplt.htm

http://www.ksh.hu/pls/ksh/docs/eng/imf/nsdp.html

http://www.stat.gov.pl/english/sdds/dane.htm

http://www.statistics.sk/webdata/mmf/nssu.htm

http://www.bsi.si/imf/

http://www.statistischedaten.de/ISAPI/DBDemo.dll/Sources?DB=EU\&File=EU\&Text=Eurostat+Statistics http://www.statistischedaten.de/ISAPI/DBDemo.dll/Sources?DB=WELT\&File=WELT\&Text=World+Statistics 
from the regression the strongly correlated time series and accommodated the chosen variables for all economies. We excluded the following variables: net export, unemployment, deflator and inflation; and we used public debt, GDP, short-term interest rate and savings as explanatory variables of shares value (i.e. potential collaterals for credit insurance) in all analysed economies. The supposition in our model is that credits to private sector (households and enterprises) are increasing.

Correlograms were used for making a decision if a model is a moving average process (MA) or an autoregressive process (AR) in OLS models (Eviews 4.0, pp. 257-206, 299-303, 312-324): if a correlogram shows that a serial correlation dies off more or less geometrically with the increasing lag, than there is a sign that the series obeys a low order autoregressive process (AR); the AR(1) technique incorporates the residual from the past observation into the regression model for the current observation. If the correlogram shows that a serial correlation dies off (that is, falls close to zero) after a small number of lags, the series obey a low order moving average process MA (Eviews 4.0, pp. 160, 260). Q-Statistics proved no serial correlation in the residuals if autocorrelations and partial autocorrelation were near zero, Q-Statistics proved to be significant with large p-values (Eviews 4.0, 2003, p. 297, more in Chen and Popovich, 2002, pp. 13-45).

For a homoskedasticity of residuals the Breusch-Godfrey LM Test (MA-models) and ARCH Test (AR-models) were used (Rubinfeld and Pyndick, 1991, pp. 250252, Eviews 4.0, 300, pp. 505-506). The null hypothesis of both test is that there is no serial correlation in the residuals up to the specified order. If the value of OBS* $\mathrm{R}^{2}$ residuals is lower than the critical value, and if probability is high, a homoskedasticity (i.e. no autocorrelation of the residuals) was proved, then we accept the hypothesis of no autocorrelation of residuals (Table 3). If autocorrelation dies off after a small number of lags, we introduced MA model and we can accept the null hypothesis of no serial autocorrelation if the Breusch-Godfrey test proved no autocorrelation because the calculated F-Statistics are lower than the critical value at high probability level (Table 3 ). In the case of AR model, we accepted the null hypothesis of no serial autocorrelation if the ARCH test proved no autocorrelation due to the calculated F-Statistics are lower than the critical value at high level of probability (Table 3 ).

The Chow Breakpoint Test was used for dividing the observed period into two parts: if the value of F-Statistic is higher than the critical value and if the probability is near to zero, the in-stability was proved and we can reject the hypothesis of structural stability and therefore we divided the model into two periods (Eviews 4.0, 2003, pp. 364-365). The Chow forecast and the Ramsey-Reset test (Ramsey, 1969, pp. 350-371, Eviews 4.0, 2003, pp. 366, 506-510) were used for proving the stability of estimated functions. Stability Ramsey-Reset test proved stability because the calculated F-Statistics are lower than the critical values at probability level different from zero (Table 4). If the value of F-Statistics is lower than the critical value and if the probability is high, the stability is proved and we can accept the hypothesis of structural stability (Table 4).

The serial autocorrelation of the variables was not improved even by AR/MA process in the case of Lithuania and the Czech Republic and according to the Chow Breakpoint test with regard to the whole period from 1999 to 2004, the values of calculated F-Statistics exceeded the critical values at low probability, we rejected 
Table 3

\section{Autocorrelation Tests for Lithuania, the Czech Republic, Hungary, Poland, Slovenia} and Slovakia

Q-Statistic probabilities adjusted for 1 ARMA term(s): from 1999:02 to 2001:12 Lithuania

\begin{tabular}{cccrrrr} 
Autocorrelation & Partial Correlation & & AC & PAC & Q-Stat & Prob \\
\hline .1 .1 & .1 .1 & 1 & 0.049 & 0.049 & 0.0701 & \\
.1 .1 & .1 .1 & 2 & -0.014 & -0.016 & 0.0760 & 0.783 \\
.$* 1.1$ &.$* 1.1$ & 3 & -0.102 & -0.101 & 0.4061 & 0.816 \\
.1 .1 & .1 .1 & 4 & -0.037 & -0.028 & 0.4525 & 0.929
\end{tabular}

Breusch-Godfrey Serial Correlation LM Test: 1999:02 to 2001:12 Lithuania

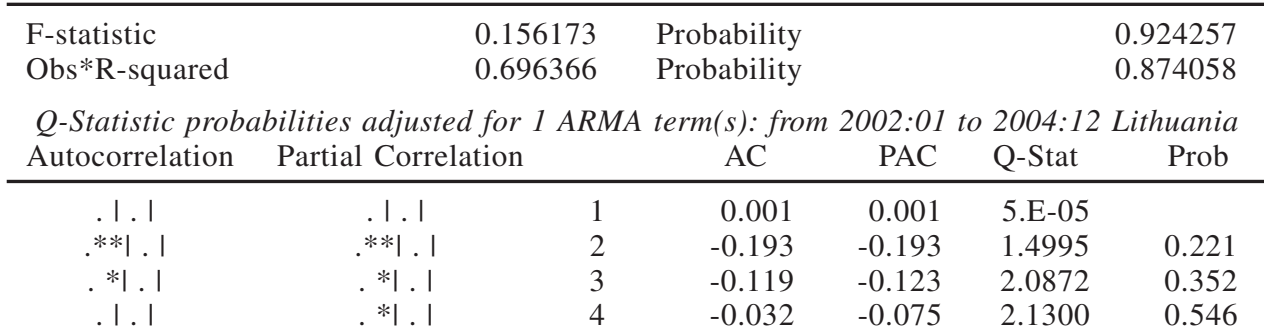

ARCH Test: from 2002:01 to 2004:12 Lithuania

\begin{tabular}{llll}
\hline F-statistic & 0.062862 & Probability & 0.992283 \\
Obs*R-squared & 0.295262 & Probability & 0.990118 \\
\hline
\end{tabular}

Breusch-Godfrey Serial Correlation LM Test: from 1996:02 to 2000:08 the Czech Republic

\begin{tabular}{lrll}
\hline F-statistic & 1.573517 & Probability & 0.303075 \\
Obs*R-squared & 9.20215 & Probability & 0.294104 \\
\hline
\end{tabular}

Breusch-Godfrey Serial Correlation LM Test: from 2000:09 to 2004:12 the Czech Republic

\begin{tabular}{|c|c|c|c|}
\hline $\begin{array}{l}\text { F-statistic } \\
\text { Obs*R-squared }\end{array}$ & $\begin{array}{l}0.865497 \\
4.855636\end{array}$ & $\begin{array}{l}\text { Probability } \\
\text { Probability }\end{array}$ & $\begin{array}{l}0.512248 \\
0.433752\end{array}$ \\
\hline \multicolumn{4}{|c|}{ ARCH Test: from1997:08 to 2004:12 Hungary } \\
\hline F-statistic & 1.069069 & Probability & 0.517020 \\
\hline Obs*R-squared & 9.11574 & Probability & 0.481574 \\
\hline \multicolumn{4}{|c|}{ Breusch-Godfrey Serial Correlation LM Test: from 1998:03 to 2004:12 Slovenia } \\
\hline F-statistic & 1.766565 & Probability & 0.427405 \\
\hline Obs*R-squared & 8.42886 & Probability & 0.433480 \\
\hline \multicolumn{4}{|c|}{ ARCH Test: from1999:02 to 2004:12 Poland } \\
\hline F-statistic & 1.227582 & Probability & 0.567286 \\
\hline Obs*R-squared & 5.56354 & Probability & 0.582306 \\
\hline \multicolumn{4}{|c|}{ ARCH Test: from 1997:02 to December 2004:12 Slovakia } \\
\hline F-statistic & 3.648406 & Probability & 0.232434 \\
\hline Obs*R-squared & 28.77456 & Probability & 0.114915 \\
\hline
\end{tabular}

Source: own calculations 2006 by Eviews 4.0 
Table 4

\section{Stability Tests for Lithuania, the Czech Republic, Hungary, Poland, Slovenia and Slovakia}

Chow Breakpoint Test: 2001:12

(regarding the whole time series from 1999:02 to 2004:12 Lithuania)

\begin{tabular}{llll}
\hline F-statistic & 504.4510 & Probability & 0.000000 \\
Log likelihood ratio & 233.6471 & Probability & 0.000000 \\
\hline
\end{tabular}

Chow Breakpoint Test: 2001:12

(regarding the whole time series from 1996:02 to 2004:12 the Czech Republic)

\begin{tabular}{|c|c|c|c|}
\hline $\begin{array}{l}\text { F-statistic } \\
\text { Log likelihood ratio }\end{array}$ & $\begin{array}{l}46.34949 \\
127.3957\end{array}$ & $\begin{array}{l}\text { Probability } \\
\text { Probability }\end{array}$ & $\begin{array}{l}0.000000 \\
0.000000\end{array}$ \\
\hline \multicolumn{4}{|c|}{ Ramsey RESET Test: from 1996:02 to 2000:08 the Czech Republic } \\
\hline F-statistic & 0.190440 & Probability & 0.964402 \\
\hline Log likelihood ratio & 1.187959 & Probability & 0.946027 \\
\hline \multicolumn{4}{|c|}{ Ramsey RESET Test: from 2000:09 to 2004:12 the Czech Republic } \\
\hline F-statistic & 0.416047 & Probability & 0.522120 \\
\hline Log likelihood ratio & 0.468200 & Probability & 0.493816 \\
\hline \multicolumn{4}{|c|}{$\begin{array}{c}\text { Chow Breakpoint Test: 1998:12 } \\
\text { (regarding the whole time series from 1997:08 to 2004:12 Hungary) }\end{array}$} \\
\hline F-statistic & 0.952667 & Probability & 0.665022 \\
\hline Log likelihood ratio & 6.565446 & Probability & 0.562908 \\
\hline \multicolumn{4}{|c|}{ Chow Breakpoint Test: 2000:01: (regarding the period from 1998:03 to 2004:12 Slovenia) } \\
\hline F-statistic & 1.285810 & Probability & 0.479405 \\
\hline Log likelihood ratio & 3.253859 & Probability & 0.419294 \\
\hline \multicolumn{4}{|c|}{ Chow Breakpoint Test: 2000:10 (regarding the period from 1999:02 to 2004:12) for Poland } \\
\hline F-statistic & 1.348243 & Probability & 0.593731 \\
\hline Log likelihood ratio & 4.710177 & Probability & 0.521198 \\
\hline \multicolumn{4}{|c|}{$\begin{array}{l}\text { Chow Breakpoint Test: 2004:01 } \\
\text { (regarding the period from 1997:02 to 2004:12) for Slovakia }\end{array}$} \\
\hline F-statistic & 0.811055 & Probability & 0.545930 \\
\hline Log likelihood ratio & 4.524946 & Probability & 0.476553 \\
\hline \multicolumn{4}{|c|}{ Chow Forecast Test: Forecast from 2000:12 to 2004:12 Slovakia } \\
\hline F-statistic & 1.055645 & Probability & 0.437182 \\
\hline Log likelihood ratio & 36.71243 & Probability & 0.216201 \\
\hline
\end{tabular}

Source: own calculations 2006 by Eviews 4.0

the null hypothesis of structural stability and re-specified the model for Lithuania and the Czech Republic (see Table 4). We had to divide the whole period into two parts; the first period from 1999 to the end of 2001; and the second period from January 2001 to December 2004 for Lithuania; and the first period from 1996 till 
August 2000 and the second period from September 2000 to December 2004 for the Czech Republic. Because the Chow Breakpoint test proved good performance of the model for the whole period due to low F-Statistics and high probability level, we did not divide the observed period into two parts in the case of Hungary, Slovakia, Slovenia and Poland.

The OLS method and VAR were used. VAR decomposition provides information about the relative importance of each random innovation in affecting the variables in the VAR (Charemza et al, 1997, pp. 176-179, 190-192). The VAR model supposes no exogenous variable, includes the number of cointegrated equations, assumes intercept and no trend in cointegrating equations and no deterministic trend in data (Engle and Granger, 1978, pp. 251-276).

Since there are significant correlations between some residuals, it is necessary to examine the sensitivity of the responses to re-ordering of the variables and in this context identification problem is related to VAR methodology. Recursive identification, which separates the residuals into orthogonal shocks using Cholesky factorisation of the covariance matrix of residuals, is the standard way to meet these requirements (Canova and Pina, 1998). Cholesky ordering in VAR analysis observes the fact that $\mathrm{P}\left(\mathrm{P}=\mathrm{G} \mathrm{D}^{-1 / 2} \mathrm{G}^{\prime}\right.$, where $\mathrm{D}$ is the diagonal matrix containing the eigenvalues of the residual covariance matrix on the diagonal and $\mathrm{G}$ is a matrix whose columns are the corresponding eigenvectors) is inverse of the lower triangular Cholesky factor of the residual covariance matrix. Recursive identification attributes all the contemporaneous correlations of the residuals to the variable that is ordered first in a model. Cholesky uses the inverse of the Cholesky factor of the resiudal covariance matrix ordering to orthogonalize the impulses (see Eviews 4.0, 2003, pp. 504511). This option imposes an ordering of the variables in the VAR and attributes all of the effect of any common component to the variable that comes first in the VAR system.

Considering VAR of order $\mathrm{p}$, where $\mathrm{y}_{\mathrm{t}}$ is a $\mathrm{k}$-vector of non-stationary variables, $\mathrm{x}_{\mathrm{t}}$ is a d-vector of deterministic variables and $\mathrm{e}_{\mathrm{t}}$ is a vector of innovations (Eviews 2003, 519):

$$
\Delta y_{t}=\Pi y_{t-1}+\sum_{i=1}^{p-1} \Gamma_{i} \Delta y_{t-i}+B x_{t}+e_{t}, \text { where } \Pi=\sum_{i=1}^{p} A_{i}-l, \Gamma_{i}=\sum_{j=1+i}^{p} A_{j}
$$

The Johansen's method is to estimate the $\Pi$ matrix from the unrestricted VAR and to test whether we can reject the restrictions implied by the reduced rank of $\Pi$.

Engle and Granger (1987, pp. 259-276) pointed out that a linear combination of two or more non-stationary series may be stationary. If such a stationary linear combination exists, the non-stationary time series are said to be cointegrated. And the presence of cointegrating relation forms the basis of the VEC specification (Eviews, 2003, pp. 519-520):

$$
y_{t}=A_{1} y_{t-1}+\ldots .+A_{p} y_{t-p}+B x_{t}+e_{t}
$$

The purpose of the cointegration test is to determine whether a group of nonstationary series are cointegrated or not. The stationary linear combination is called the cointegrating equation and may be intepreted as a long-run equlibrium relationship among the observed variables (Charemza and Deadman, 1997, pp. 228-230). The test assumes unrestricted cointegration, intercept no trend of the se- 
Table 5

Cointegration between Collaterals and GDP

\begin{tabular}{|c|c|c|c|c|}
\hline Czech Rep. (lags 1-4) & & Trace & 5 Percent & 1 Percent \\
\hline & Eigenvalue & Statistic & Critical Value & Critical Value \\
\hline & 0.091764 & 15.76745 & 15.41 & 20.04 \\
\hline & 0.056663 & 5.949809 & 3.76 & 6.65 \\
\hline & & Max-Eigen & 5 Percent & 1 Percent \\
\hline & Eigenvalue & Statistic & Critical Value & Critical Value \\
\hline & 0.091764 & 9.817644 & 14.07 & 18.63 \\
\hline & 0.056663 & 5.949809 & 3.76 & 6.65 \\
\hline
\end{tabular}

Trace test indicates no cointegration at the $1 \%$ level.

Max-eigenvalue test indicates no cointegration at both 5\% and $1 \%$ levels.

\begin{tabular}{|c|c|c|c|c|}
\hline Hungary (lags1 - 2) & & Trace & 5 Percent & 1 Percent \\
\hline & Eigenvalue & Statistic & Critical Value & Critical Value \\
\hline & 0.148007 & 13.86030 & 15.41 & 20.04 \\
\hline & 0.000989 & 0.085095 & 3.76 & 6.65 \\
\hline & & Max-Eigen & 5 Percent & 1 Percent \\
\hline & Eigenvalue & Statistic & Critical Value & Critical Value \\
\hline & 0.148007 & 13.77520 & 14.07 & 18.63 \\
\hline & 0.000989 & 0.085095 & 3.76 & 6.65 \\
\hline
\end{tabular}

Trace test indicates no cointegration at both 5\% and $1 \%$ levels.

Max-eigenvalue test indicates no cointegration at both 5\% and $1 \%$ levels.

\begin{tabular}{|c|c|c|c|c|}
\hline Lithuania (lags 1-2) & & Trace & 5 Percent & 1 Percent \\
\hline & Eigenvalue & Statistic & Critical Value & Critical Value \\
\hline & 0.136726 & 12.09834 & 15.41 & 20.04 \\
\hline & 0.046973 & 2.982935 & 3.76 & 6.65 \\
\hline & & Max-Eigen & 5 Percent & 1 Percent \\
\hline & Eigenvalue & Statistic & Critical Value & Critical Value \\
\hline & 0.136726 & 9.115410 & 14.07 & 18.63 \\
\hline & 0.046973 & 2.982935 & 3.76 & 6.65 \\
\hline
\end{tabular}

Trace test indicates no cointegration at both $5 \%$ and $1 \%$ levels.

Max-eigenvalue test indicates no cointegration at both 5\% and $1 \%$ levels. 


\begin{tabular}{|c|c|c|c|c|}
\hline Poland (lags 1-2) & & Trace & 5 Percent & 1 Percent \\
\hline & Eigenvalue & Statistic & Critical Value & Critical Value \\
\hline & 0.145076 & 15.84689 & 15.41 & 20.04 \\
\hline & 0.073461 & 5.188347 & 3.76 & 6.65 \\
\hline & & Max-Eigen & 5 Percent & 1 Percent \\
\hline & Eigenvalue & Statistic & Critical Value & Critical Value \\
\hline & 0.145076 & 10.65854 & 14.07 & 18.63 \\
\hline & 0.073461 & 5.188347 & 3.76 & 6.65 \\
\hline
\end{tabular}

Trace test indicates no cointegration at the $1 \%$ level.

Max-eigenvalue test indicates no cointegration at both 5\% and $1 \%$ levels.

\begin{tabular}{|c|c|c|c|c|}
\hline Slovakia (lags 1-2) & & Trace & 5 Percent & 1 Percent \\
\hline & Eigenvalue & Statistic & Critical Value & Critical Value \\
\hline & 0.117685 & 15.13903 & 15.41 & 20.04 \\
\hline & 0.038585 & 3.620106 & 3.76 & 6.65 \\
\hline & & Max-Eigen & 5 Percent & 1 Percent \\
\hline & Eigenvalue & Statistic & Critical Value & Critical Value \\
\hline & 0.117685 & 11.51892 & 14.07 & 18.63 \\
\hline & 0.038585 & 3.620106 & 3.76 & 6.65 \\
\hline
\end{tabular}

Trace test indicates no cointegration at both $5 \%$ and $1 \%$ levels.

Max-eigenvalue test indicates no cointegration at both 5\% and $1 \%$ levels.

\begin{tabular}{|c|c|c|c|c|}
\hline Slovenia (lags 1-2) & & Trace & 5 Percent & 1 Percent \\
\hline & Eigenvalue & Statistic & Critical Value & Critical Value \\
\hline & 0.192908 & 22.83634 & 15.41 & 20.04 \\
\hline & 0.072025 & 5.905250 & 3.76 & 6.65 \\
\hline & & Max-Eigen & 5 Percent & 1 Percent \\
\hline & Eigenvalue & Statistic & Critical Value & Critical Value \\
\hline & 0.192908 & 16.93109 & 14.07 & 18.63 \\
\hline & 0.072025 & 5.905250 & 3.76 & 6.65 \\
\hline
\end{tabular}

Trace test indicates 1 cointegrating equation(s) at the $1 \%$ level.

Max-eigenvalue test indicates no cointegration at the $1 \%$ level.

Source: own calculations by Eviews 4.0

ries in the cointegration relation and no exogenous variable. If critical values of the calculated statistics (Trace-statistic and Max-eigenvalue) are higher than critical values at $1 \%$ and at $5 \%$ level of significance, we can reject the hypothesis $\mathrm{H}$ (i.e. 
no cointegration) in favour of cointegration (Eviews 4.0, 2003, pp. 518-520). We tested the correlation between collaterals value and GDP growth by Johansen test. If critical values of the calculated statistics are lower than critical values at $1 \%$ and at $5 \%$ level of significance, we can reject the hypothesis $\mathrm{H}_{0}$ of cointegration in favour of the hypothesis of no cointegration (i.e. no procyclicality between GDP and collaterals value).

According to Trace-test and Max-eigenvalue test no cointegration at 1\% and 5\% significance level between collaterals value and GDP was proved, which means that there is no procyclicality in Lithuania. For the Czech Republic the cointegration tests proved no cointegration at $1 \%$ and $5 \%$ significance level according to eigenvalue; and according to Trace-test no cointegration was proved only at $1 \%$ significance level. Trace-test and Max-eigenvalue proved no cointegration at $1 \%$ and $5 \%$ significance level for Hungary. The results obtained by Trace-test and Max-eigenvalue for Slovenia are conflicting. The Max-eigenvalue proved no cointegration only at $1 \%$ significance level for Slovenia. For Poland, the cointegration tests proved no cointegration at $1 \%$ and 5\% significance level according to eigenvalue and according to Trace-test no cointegration was proved only at $1 \%$ significance level. Both cointegration tests proved no cointegration at $1 \%$ and $5 \%$ significance level for Slovakia.

\section{2 Empirical Results}

A good performance of the second period model was proved with regard to actual, fitted and residual values (figures in the Appendix). Collaterals value and GDP growth proved no significant procyclicality. There is no long-run cointegration between GDP and collaterals value in the analysed transition economies (Table 5).

- The persistence in collaterals value over time account for $5.35 \%$ of the variation in collaterals value over the 24-month horizon; shocks to debt account for about $13.12 \%$ of the variation in collaterals value; shocks to GDP account for about $2.98 \%$ of the variation in collaterals value over the 24-month horizon; shocks to short-run interest rate account for $47.35 \%$ of the variation in collaterals value over the 24month horizon; shocks to savings account for $13.12 \%$ of the variation in collaterals value over the 24-month horizon in the first time period for Lithuania.

- The persistence in collaterals value over time account for $1.00 \%$ of the variation in collaterals over the 24-month horizon; shocks to debt account for about $23.03 \%$ of the variation in collaterals; shocks to GDP account for about $2.37 \%$ of the variation in collaterals over the 24-month horizon; shocks to short-run interest rate account for $48.27 \%$ of the variation in collaterals over the 24-month horizon; shocks to savings account for $25.30 \%$ of the variation in collaterals value over the 24-month horizon in the second time period for Lithuania.

The variance decomposition for the period from 1996:02 to 2000:08 for the Czech Republic gave the following results:

- The persistence in collaterals over time account for $3.75 \%$ of the variation in collaterals over the 24-month horizon; shocks to debt account for about $2.58 \%$ of the variation in collaterals; shocks to GDP account for about $2.79 \%$ of the variation in collaterals over the 24-month horizon; shocks to short-run interest rate account 
Table 6

\section{Variance Decomposition for Lithuania, the Czech Republic, Hungary, Poland,} Slovakia and Slovenia

Variance decomposition of collaterals value, ordering Cholesky: debt, GDP, interest rate, savings and collaterals value; lag 3-5 months for edogenous variable: 1999:02 to 2001:12 Lithuania.

\begin{tabular}{cccccc} 
Period & DEBT & GDP & INTR & SAVINGS & COLLATERALS \\
\hline 12 & 18.03154 & 4.788451 & 35.67717 & 33.20526 & 8.297587 \\
24 & 13.12238 & 2.985670 & 47.35862 & 31.18237 & 5.350960
\end{tabular}

Variance decomposition of collaterals value, ordering Cholesky: debt, GDP, interest rate, savings and collaterals; lag 3-5 months for endogenous variable: from 2002:01 to 2004:12 Lithuania.

\begin{tabular}{cccccc} 
Period & DEBT & GDP & INTR & SAVINGS & COLLATERALS \\
\hline 12 & 25.87412 & 2.874763 & 39.52971 & 27.59626 & 4.12515 \\
24 & 23.03994 & 2.372267 & 48.27540 & 25.30670 & 1.00570
\end{tabular}

Variance decomposition of collaterals value, ordering Cholesky: debt, savings, interest rate, GDP and collaterals; lag 3-5 months for endogenous variable: from 1996:02 to 2000:08 the Czech Republic.

\begin{tabular}{cccccc} 
Period & DEBT & SAVINGS & INTR & GDP & COLLATERALS \\
\hline 12 & 8.438076 & 52.05083 & 24.97081 & 10.61096 & 3.929324 \\
24 & 2.589182 & 56.69647 & 34.16788 & 2.795590 & 3.750879
\end{tabular}

Variance decomposition of collaterals value, ordering Cholesky: debt, savings, interest rate, GDP and collaterals; lag 3-5 months for endogenous variable: from 2000:09 to 2004:12 the Czech Republic.

\begin{tabular}{cccccc} 
Period & DEBT & SAVINGS & INTR & GDP & COLLATERALS \\
\hline 12 & 3.587234 & 32.57863 & 46.76359 & 11.08173 & 5.988808 \\
24 & 2.985965 & 36.42948 & 49.17909 & 7.684339 & 3.721117
\end{tabular}

Variance decomposition: Cholesky ordering: debt, GDP, savings, interest rate, collaterals, lag 3-12 months for endogenous variable: from 1997:08 to 2004:12 Hungary.

\begin{tabular}{ccrrrc} 
Period & DEBT & \multicolumn{1}{c}{ GDP } & SAVINGS & \multicolumn{1}{c}{ INTR } & COLLATERALS \\
\hline 12 & 12.67049 & 13.729800 & 36.35442 & 32.94591 & 4.299370 \\
24 & 11.55989 & 9.341438 & 42.94489 & 36.01055 & 0.143227 \\
36 & 11.35499 & 9.319347 & 42.05544 & 37.12931 & 0.140919
\end{tabular}

Variance decomposition: Cholesky ordering: debt, GDP, interest rate, savings, collaterals, lag 3-12 months for endogenous variable: from 1998:03 to 2004:12 Slovenia.

\begin{tabular}{cccccc} 
Period & DEBT & GDP & INTR & SAVINGS & COLLATERALS \\
\hline 12 & 18.93921 & 11.37673 & 33.54160 & 28.20128 & 7.94118 \\
24 & 17.33005 & 12.75928 & 36.59317 & 39.69916 & 3.61834 \\
36 & 17.63237 & 12.83993 & 39.24751 & 38.83207 & 1.44812
\end{tabular}

Variance decomposition: Cholesky ordering: debt, GDP, savings, interest rate, collaterals, lag 3-12 for endogenous variable: from 1999:02 to 2004:12 Poland.

\begin{tabular}{ccrrcc} 
Period & DEBT & \multicolumn{1}{c}{ GDP } & SAVINGS & INTR & COLLATERALS \\
\hline 12 & 20.77303 & 13.169039 & 32.25962 & 33.79656 & 0.001743 \\
24 & 15.00595 & 8.183911 & 42.21053 & 34.59582 & 0.003786 \\
36 & 15.35474 & 9.558768 & 41.43724 & 33.64761 & 0.001646
\end{tabular}

Variance decomposition Cholesky ordering: debt, GDP, interest rate, savings, collaterals, lag 3-12 months for endogenous variable: from 1997:02 to 2004:12 Slovakia.

\begin{tabular}{ccccrc} 
Period & DEBT & GDP & INTR & SAVINGS & COLLATERALS \\
\hline 12 & 16.20542 & 12.81631 & 33.56413 & 30.71336 & 6.700783 \\
24 & 13.22254 & 11.37920 & 34.87220 & 37.23361 & 3.292438 \\
36 & 16.82245 & 12.85704 & 31.54527 & 37.52999 & 1.245257
\end{tabular}

Source: Own calculations by Eviews 4.0. 
for $34.16 \%$ of the variation in collaterals over the 24-month horizon; shocks to savings account for $56.69 \%$ of the variation in collaterals' over the 24 -month horizon.

The variance decomposition for the period from 2000:09 to 2004:12 in the Czech Republic gave the following results:

- The persistence in collaterals over time account for $3.72 \%$ of the variation in collaterals over the 24-month horizon; shocks to debt account for about $2.98 \%$ of the variation in collaterals; shocks to GDP account for about $7.68 \%$ of the variation in collaterals over the 24-month horizon; shocks to short-run interest rate account for $49.17 \%$ of the variation in collaterals over the 24-month horizon; shocks to savings account for $36.42 \%$ of the variation in collaterals over the 24 -month horizon.

The variance decomposition uses up to 36-month horizon and the ordering of Cholesky for Hungary. The variance decomposition for the period from 1997:08 to 2004:12 gave the following results:

- Shocks to debt account for about $11.35 \%$ of the variation in collaterals value; shocks to GDP account for about $9.31 \%$ of the variation in collaterals value over the 36-month horizon; shocks to short-run interest rate account for $37.13 \%$ of the variation in collaterals value over the 36-month horizon; shocks to savings account for $42.05 \%$ of the variation in collaterals value over the 36-month horizon.

The variance decomposition uses up to 36-month horizon and gave the following results for Slovenia:

- The persistence in collaterals value over time account for $1.44 \%$ of the variation in collaterals value over the 36-month horizon; shocks to debt account for about $17.33 \%$ of the variation in collaterals value; shocks to GDP account for about $12.83 \%$ of the variation in collaterals' value over the 36-month horizon; shocks to short-run interest rate account for $39.24 \%$ of the variation in collaterals value over the 36-month horizon; shocks to savings account for $38.83 \%$ of the variation in collaterals' value over the 36-month horizon.

The variance decomposition used up to 36-month horizon and gave the following results for Poland:

- Shocks to debt account for about $15.35 \%$ of the variation in collaterals value; shocks to GDP account for about $9.55 \%$ of the variation in collaterals value over the 36-month horizon; shocks to short-run interest rate account for $33.64 \%$ of the variation in collaterals value over the 36-month horizon; shocks to savings account for $41.43 \%$ of the variation in collaterals' value over the 36-month horizon.

The variance decomposition gave the following results for Slovakia:

- Shocks to debt account for about $16.82 \%$ of the variation in collaterals; shocks to GDP account for about $12.85 \%$ of the variation in collaterals value over the 36month horizon; shocks to short-run interest rate account for $131.54 \%$ of the variation in collaterals over the 36-month horizon; shocks to savings account for $37.52 \%$ of the variation in collaterals over the 36 -month horizon. 


\section{Model 1}

Lithuania: Least Squares - regarding the period from 1999:02 to 2001:12

$$
\begin{aligned}
& \mathrm{Ln}(\text { collaterals })=0.922 \ln (\operatorname{debt}(-2))+0.009 \ln (\mathrm{GDP}(-3))-0.809 \ln (\text { interest rate })+0.781 \ln (\text { savings }(-1))+0.575 \mathrm{MA}(1) \\
& \begin{array}{lllll}
\text { t-Statistic } & (13.689) & (+2.154) & (-12.743) & (+11.289)
\end{array} \\
& \begin{array}{lllll}
\text { Probabilty } & (0.000) & (0.043) & (0.000) & (0.000)
\end{array} \\
& \mathrm{R} 2=0.86 \\
& \mathrm{DW}=1.88
\end{aligned}
$$

Model 2

\section{Lithuania: Least Squares - regarding period from 2002:01 to 2004:12}

$$
\begin{aligned}
& \operatorname{Ln}(\text { collaterals })=-1.243(\operatorname{debt}(-2))+0.553 \ln (\mathrm{GDP}(-3))-1.918 \ln (\text { interest rate }(-1))+1.773 \ln (\text { savings }(-4))+0.679 \mathrm{AR}(1) \\
& \begin{array}{lllll}
\mathrm{t} \text {-Statistic } & (-7.317) & (3.399) & (-45.195) & (3.934)
\end{array} \\
& \begin{array}{lllll}
\text { Probabilty } & (0.000) & (0.001) & (0.000) & (0.000)
\end{array} \\
& \mathrm{R} 2=0.89 \\
& \mathrm{DW}=1.79
\end{aligned}
$$

Model 1

Czech Republic: Least Squares - regarding the period from 1996:02 to 2000:08

$$
\begin{aligned}
& \mathrm{Ln}(\text { collaterals })=-0.150 \ln (\text { int }(-2))+0.025 \ln (\operatorname{debt}(-4))+1.099 \ln (\text { savings }(-3))+0.058 \ln (\mathrm{GDP}(-5))+0.940 \mathrm{MA}(1) \\
& \begin{array}{lllll}
\mathrm{t}-\text { Statistic } & (-3.999) & (2.031) & (+14.532) & (6.025)
\end{array} \\
& \begin{array}{lllll}
\text { Probabilty } & (0.000) & (0.048) & (0.000) & (0.000)
\end{array}
\end{aligned}
$$

$\mathrm{R} 2=0.84$

$\mathrm{DW}=1.31$

Model 2

Czech Republic: Least Squares - regarding the period from 2000:09 to 2004:12

$$
\begin{array}{lccccc}
\operatorname{Ln}(\text { collaterals })= & 0.887 \ln (\text { debt }) & -2.596 \ln (\operatorname{intr}(-2)) & +2.609 \ln (\text { savings }(-5)) & +1.057 \ln (\operatorname{GDP}(-4))+0.813 \mathrm{MA}(1) \\
\text { t-Statistic } & (3.8237) & (-21.032) & (13.624) & (3.309) & (8.920) \\
\text { Probabilty } & (0.000) & (0.000) & (0.000) & (0.001) & (0.000) \\
\text { R2 }=0.87 & & & & \\
\text { DW }=1.66 & & &
\end{array}
$$

\section{Model for Hungary: the period from 1997:08 to 2004:12}

$$
\begin{array}{lccccc}
\operatorname{Ln}(\text { collaterals })= & -0.286 \ln (\operatorname{debt}(-6)) & +0.409 \ln (\mathrm{GDP}(-7)) & +1.052 \ln (\text { savings }) & -0.685 \ln (\operatorname{intr}(-4))+0.980 \mathrm{AR}(1) \\
\text { t-Statistic } & (-2.700) & (3.966) & (31.673) & (-2.959) & (100.521) \\
\text { Probabilty } & (0.008) & (0.000) & (0.000) & (0.004) & (0.000) \\
\text { R2 }=0.88 & & & & & \\
\text { DW }=1.87 & & & &
\end{array}
$$

\section{Model for Slovenia: from 1998:03 to 2004:12}

$$
\begin{aligned}
& \mathrm{Ln}(\text { collaterals })=-0.303 \ln (\operatorname{debt}(-10))-1.207 \ln (\text { intr })+0.651 \ln (\mathrm{GDP})+1.195 \ln (\operatorname{savings}(-4))+0.886 \mathrm{MA}(1) \\
& \text { t-Statistic (-5.040) (-21.717) (8.015) } \\
& \begin{array}{lllll}
\text { Probabilty } & (0.000) & (0.000) & (0.000) & (0.000)
\end{array} \\
& \mathrm{R} 2=0.86 \\
& \mathrm{DW}=1.29
\end{aligned}
$$


Model for Poland: the period from 1999:02 to 2004:12

$\begin{array}{lccccc}\text { Ln }(\text { collaterals })= & -0.264 \ln (\text { debt(-13) }) & -1.797 \ln (\text { intr(-1) }) & +0.484 \ln (\text { GDP }(-6)) & +2.152 \ln (\text { savings }(-12)) & +0.981 \mathrm{AR}(1) \\ \text { t-Statistic } & (-2.496) & (-23.909) & (4.383) & (+2.737) & (26.648) \\ \text { Probabilty } & (0.015) & (0.000) & (0.001) & (0.008) & \\ \text { R2 }=0.88 & & & & \end{array}$

Model for Slovakia: the time period from 1997:02 to 2004:12

$\begin{array}{lccccc}\operatorname{Ln}(\text { collaterals })= & 0.212 \ln (\operatorname{debt}(-12)) & -0.401 \ln (\operatorname{intr}(-8)) & +0.056 \ln (\mathrm{GDP}(-8)) & +0.843 \ln (\text { savings }(-10)) & +0.998 \mathrm{AR}(1) \\ \mathrm{t}-\text { Statistic } & (4.4462) & (-2.6739) & (2.2114) & (3.1365) & (128.16) \\ \text { Probabilty } & (0.000) & (0.0093) & (0.0302) & (0.0025)\end{array}$

$\mathrm{R} 2=0.98$

DW=1.97

Source: own calculations 2006 by Eviews 4. 0

\section{Lithuania}

The elasticity of collaterals value on GDP movements (0.009) is insignificant according to the OLS for the period from 1999 till the end of 2001 and higher in the period from 2002 to 2004 (0.553). Shocks to GDP account for about $2.98 \%$ of the variation in collaterals value over the 24-month horizon; and shocks to interest rate and savings are significant in the first period. Shocks to interest rate account for about $48.27 \%$ of the variation in collaterals' value over the 24 -month horizon in the second period from 2002 to 2004, while shocks to GDP account for only $2.37 \%$ of the variation in collaterals value over the 24 -month horizon. Significant procyclicality between collaterals value and GDP was not proved even in the long run. According to Trace-test and Max-eigenvalue test no cointegration at $1 \%$ and $5 \%$ significance level between collaterals value and GDP was proved, which means no procyclicality. We can accept financial stability hypothesis for Lithuania according to no-cointegration, according to low elasticity coefficients of collaterals value on GDP movements and according to insignificant \% of GDP as explanatory variable in variance decomposition. Interest rate and savings proved to be significant explanatory variables of collaterals' value movements in the time period of 36 months.

\section{The Czech Republic}

Savings are the most significant variable influencing collaterals value according to OLS from 1996 to 2000, while the elasticity of collaterals' value on GDP is insignificant in the first period (0.058). The elasticities of collaterals on explanatory variables increase significantly in the second period. The elasticity of collaterals value on interest rate increases significantly $(-2.596)$ in the period from 2001 to 2004. Shocks to GDP account for about $2.79 \%$ of the variation in collaterals value over the 24-month horizon; and shocks to savings account for $56.69 \%$ of the variation in collaterals value over the 24-month horizon in the first observed period. Shocks to GDP account for about $7.68 \%$ of the variation in collaterals value, shocks 
to interest rate account for about $49.17 \%$ of the variation in collaterals value in the second observed period. The cointegration tests proved no cointegration at $1 \%$ and $5 \%$ significance level according to eigenvalue; and according to Trace-test no cointegration was proved only at $1 \%$ significance level. We can accept the hypothesis of no procyclicality between GDP and collaterals value in the Czech Republic in the long run. Interest rate and savings proved to be significant explanatory variables of collaterals' value movements in the time period of 36 months.

\section{Hungary}

The elasticity of collaterals on GDP is relatively low (0.409); and the elasticity of collaterals on savings is relatively high (1.052) according to OLS. Shocks to GDP account for about $9.32 \%$ of the variation in collaterals value over the 36-month horizon and shocks to interest rate and savings are significant in the period from 1997 to 2004 (they account for about $37.12 \%$ and $42.05 \%$ of the variation in collaterals value) in the same time horizon. No procyclicality between collaterals value and GDP was proved in the short run for Hungary according to OLS and VAR, as well as the Trace-test and Max-eigenvalue proved no cointegration at $1 \%$ and 5\% significance level in the long run. Interest rate and savings proved to be significant explanatory variables of collaterals' value movements in the time period of 36 months.

\section{Slovenia}

Collaterals value movements are relatively insignificantly influenced by GDP according to elasticity coefficient (0.651), while the elasticities of collaterals on interest rates (-1.207) and savings (1.195) are significant. Shocks to interest rate account for about $39.24 \%$ of the variation in collaterals value, shocks to savings account for $38.83 \%$ of the variation in collaterals value over the 36-month horizon and shocks to GDP account for about $12.83 \%$ of the variation in collaterals value over the same time horizon in the period from 1998 to 2004. The Max-eigenvalue test proved no cointegration only at $1 \%$ significance level in Slovenia. We can confirm no short and no long-run procyclicality between collaterals value and GDP in Slovenia due to relatively low elasticity coefficient of collaterals value on GDP movements, and due to relatively low $\%$ of GDP as explanatory variable in variance decomposition of collaterals movements as well as due to the acceptable Johansen test.

\section{Poland}

Collaterals values are influenced significantly by savings (2.152) and interest rate $(-1.797)$ according to OLS, while the elasticity of collaterals value on GDP $(0.484)$ is relatively low. Shocks to GDP account for about $9.56 \%$ of the variation in collaterals value over the 36-month horizon; shocks to short-run interest rate account for $33.64 \%$ of the variation in collaterals value over the 36-month horizon; shocks to savings account for $41.43 \%$ of the variation in collaterals value over the 36 -month horizon in the period from 1999 to 2004. The cointegration tests proved no cointegration at $1 \%$ and 5\% significance level according to eigenvalue; and according to Trace-test no cointegration was proved only at $1 \%$ significance level. We can ac- 
cept the hypothesis of no procyclicality between collaterals value and GDP in long run as well as in the short run according to a relatively low elasticity coefficient of collaterals value on GDP movements; VAR results proved no procyclicality due to low \% of GDP (lower than $13.16 \%$ in the time period longer than 12 months) as explanatory variable in variance decomposition of collaterals value.

\section{Slovakia}

According to regression the elasticity coefficient of collaterals value on GDP is insignificant (0.056) and the elasticity of collaterals value on savings/interest rate is relatively significant $(0.843 /-0.401)$ in the period form 1997 to 2004 . Shocks to GDP account for about $12.85 \%$ of the variation in collaterals value, shocks to savings account for about $37.52 \%$ of the variation in collaterals value and shocks to interest rate account for about $31.54 \%$ of the variation in collaterals value over the 36-month horizon. Both cointegration tests proved no cointegration at $1 \%$ and $5 \%$ significance level for Slovakia. Low elasticity coefficient and significant no-cointegration tests proved no procyclicality between collaterals value and GDP, \% of GDP as explanatory variable in variance decomposition of collaterals value is insignificant (lower than $13 \%$ in the time period longer than 12 months).

Table 7

\section{Procyclicality between Collaterals Value GDP ${ }^{\mathrm{b}}$}

\begin{tabular}{|l|c|c|c|c|c|}
\hline & $\begin{array}{c}\text { VAR - \% of collaterals } \\
\text { value movements } \\
\text { explained by GDPa }\end{array}$ & $\begin{array}{c}\text { VAR - \% of collaterals } \\
\text { value movements } \\
\text { explained by savings }\end{array}$ & $\begin{array}{c}\text { VAR }-\% \text { of collaterals } \\
\text { value movements } \\
\text { explained by interest rate }\end{array}$ & $\begin{array}{c}\text { elasticities of } \\
\text { collaterals on } \\
\text { GDP movements }\end{array}$ & $\begin{array}{c}\text { Cointegration } \\
\text { - number of no } \\
\text { cointegrating } \\
\text { equations }\end{array}$ \\
\hline Lithuania & $(2.98+2.37)=2.67$ & $(31.18+25.30)=28.24$ & $(47.36+48.27)=47.81$ & $(0.009+0.553)=0.28$ & 4 \\
\hline $\begin{array}{l}\text { Czech } \\
\text { Republic }\end{array}$ & $(2.79+7.68)=5.25$ & $(56.69+36.42)=46.55$ & $(34.16+49.17)=41.66$ & $(0.058+1.057)=0.560$ & 3 \\
\hline Hungary & 9.34 & 42.94 & 36.01 & 0.409 & 4 \\
\hline Poland & 8.18 & 42.21 & 34.59 & 0.484 & 3 \\
\hline Slovenia & 12.75 & 39.69 & 36.59 & 0.651 & 1 \\
\hline Slovakia & 11.37 & 37.23 & 34.87 & 0.056 & 4 \\
\hline
\end{tabular}

${ }^{a}$ the average of two periods for the Czech Republic and Lithuania

${ }^{b}$ the time period of 24 months is observed

Source: Own calculations by Eviews 4.0.

The elasticity of collaterals value on GDP movements proved to be low in Slovakia and Lithuania, relatively low in Poland and Hungary and insignificantly higher in Slovenia and the Czech Republic. Shocks to GDP account for a low \% of the variation in collaterals value over the 24 and 36-month horizon in Lithuania and Czech Republic; meanwhile the shocks to GDP movements account for about $8.18 \%$ to $12.75 \%$ of the variation in collaterals value over the 24 -month horizon in Poland, Hungary, Slovenia and Slovakia. Shocks to savings account for a high \% of the 
variation in collaterals value over the 24-month horizon in the Czech Republic, Hungary and Poland on the interval of $42.21 \%$ to $46.55 \%$, meanwhile the shocks to savings account for about $28.24 \%$ to $39.69 \%$ of the variation in collaterals value over the 24-month horizon in Lithuania, Slovenia and Slovakia. Shocks to interest rate account for a high \% of the variation in collaterals value over the 24-month horizon in the Czech Republic (41.66\%) and Lithuania (47.81\%), meanwhile the shocks to interest rate movements account for about $34.59 \%$ to $36.59 \%$ of the variation in collaterals value over the 24-month horizon in Hungary, Poland, Slovenia and Slovakia.

Long-run procyclicality between collaterals value and GDP was significantly not proved for any of the studied economies. Hungary, Lithuania and Slovakia significantly proved no procyclicality between collaterals value and GDP due to 4 equations confirming no cointegration. No cointegration was proved by 3 equations for Poland and the Czech Republic. And only 1 equation proved no cointegration for Slovenia. Collaterals value movements proved to be significantly explained by savings and interest rate movements in the time period of 24 to 36-months.

\section{Conclusion}

Economic environment is characterised by favourable conditions and this contributed to positive developments observed in most NMSs banking sectors. Performance of the banking sector improved due to higher lending growth, lower provisioning costs and technology transfers etc. and the main factors underlying this trend were a reduction in economic and financial uncertainty due to sound fiscal and monetary policies. The stock market capitalization is low.

The extent that measures financial risk is inappropriately procyclical and the financial system may be excessively procyclical. Economic expansion leading to higher wealth can be observed in surging real estate and equity prices. Higher level of wealth, which eventually emerges, increases creditworthiness of private sector, while simultaneously comforting credit institutions, which find support in more valuable collateral. Collapsing asset prices reduce the value of collaterals that borrowers can use to secure loans and the ability to borrow. Due to the structure of market risk, equity as an important weight in the balance sheet position of firms, due to the fact that equity risk is determined by unstable development of share prices, equity risk as a risk of securities falling in value that arises from developments on the capital market due to fluctuations of the financial results of issuers, economic expectations, changes in market interest rates and exchange rates, (less pronounced) cyclical movements, we have exposed the relation between stock exchange market to the real economy and its correlation to procyclicality.

We answered the following questions: First, there is no significant procyclicality between financial and real sector in Lithunia, Slovenia, the Czech Republic, Poland, Slovakia and Hungary. Shocks to GDP account for a low \% of the variation in collaterals value in the analysed economies, we proved no cointegration between GDP and collaterals; elasticity coefficient of collaterals value movements are low in the analysed transition economies. Second, relatively stable development of share prices on the capital market lowers equity risk; and we accepted the hypothesis of lower equity risk (as a part of market risk) determined by macro performance in 
the analysed economies. Third, the explanation for collaterals value movements could be explained by savings and interest rate movements. Fourth, the impact of debt in terms of elasticity coefficient is of lower significance as well as shocks to debt account for low $\%$ of the variation in collaterals value over the observed time horizon.

The benefits of the more stable macroeconomic environment, less pronounced cyclical movements and stable monetary policy are not sufficient for stable financial and banking system nowadays. What is being suggested here is that banking sector imbalances, both domestic and international, need more systematic attention, and that this might be accomplished through an evolutionary adaptation of the current policy framework on micro level.

\section{Key to symbols:}

A, B: coefficients of k-vector of non-stationary variables and coefficients of d-vector of deterministic variables

AR: Autoregressive Process

ARCH: Autocorrelation Test for Autoregressive Process

Breusch-Godfrey LM Test: Autocorrelation Test for Moving Average Process

CEE: Central European Economies

C/I: Cost / Income Ratio

EBRD: European Bank for Reconstruction and Development

ECB: European Central Bank

EU: European Union

$\mathrm{e}_{\mathrm{t}}$ : vector of innovations in time $\mathrm{t}$

$\mathrm{E}\left[\Delta z_{i, j}(t)\right]$ : expected value of correlation between macro variables $\mathrm{i}$ and $\mathrm{j}$ in time period $\mathrm{t}$

F-Statistic: Structural Stability Statistic

GDP: Gross Domestic Product

HCPI: Harmonised Consumer Price Index

MA: Moving Average Process

M/S\&P: Moody's/Standard and Poor's Indicators

NMSs: New Member States

NPL: Non-Performing Loans

OBS*R ${ }^{2}$ : Observed Coefficient of Determination - Multiple

OLS: Ordinary Least Squares Residuals

p: probability value

PD: probability of default

$\rho_{\text {factor }}(i, j)$ : probability factor of correlated macro economic variables $i$ and $j$

$\mathrm{P}=\mathrm{G} \mathrm{D}^{-1 / 2} \mathrm{G}$ : $\mathrm{D}$ diagonal matrix containing the eigenvalues of the residual covariance matrix on the diagonal; G: matrix whose columns are the corresponding eigenvectors inverse of the lower triangular Cholesky factor of the residual covariance matrix

Q-Statistic: Autocorrelation Statistic

RoA: Return on Assets

VAR: variance decomposition method

$\mathrm{X}_{\mathrm{t}}$ : value of variable $\mathrm{x}$ in a time period $\mathrm{t}$ 
$\mathrm{x}_{\mathrm{t}}$ : d-vector of deterministic variables $\mathrm{y}_{\mathrm{t}}$ : $\mathrm{k}$-vector of non-stationary variables

$\mathrm{zi}_{\mathrm{j} \text { : } \mathrm{m}}$ acro economic variables $\mathrm{i}$ and $\mathrm{j}$ - as explanatory economic variable $\sigma:$ Variance

$\Pi$ : matrix from the unrestricted VAR

$\Gamma_{\mathrm{i}}=\sum_{-j=1+i}^{p} A_{j}:$ matrix from the unrestricted VAR reduced for rank

\section{Appendix}

Figure 1

Actual, Fitted and Residual Values for Lithuania from 1999:02 to 2001:12

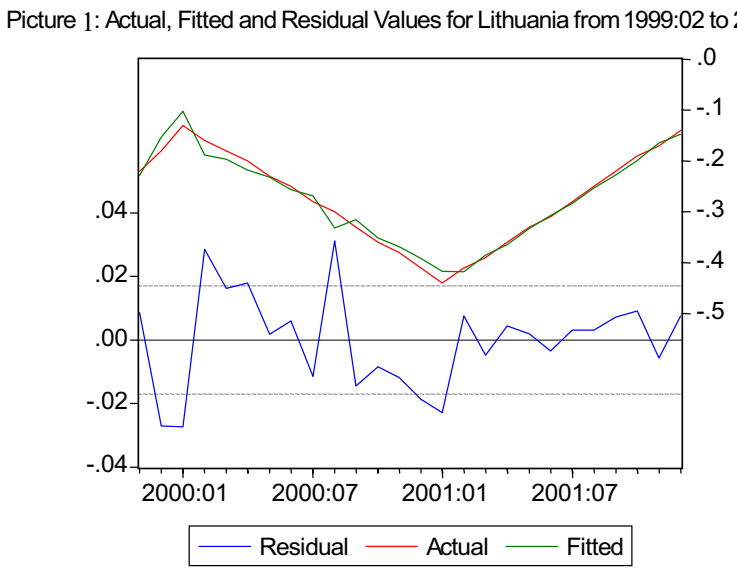

Figure 2

Actual, Fitted and Residual Values for Lithuania from 2002:01 to 2004:12

Picture 2: Actual, Fitted and Residual Values for Lithuania from 2002:01 to 2004:12

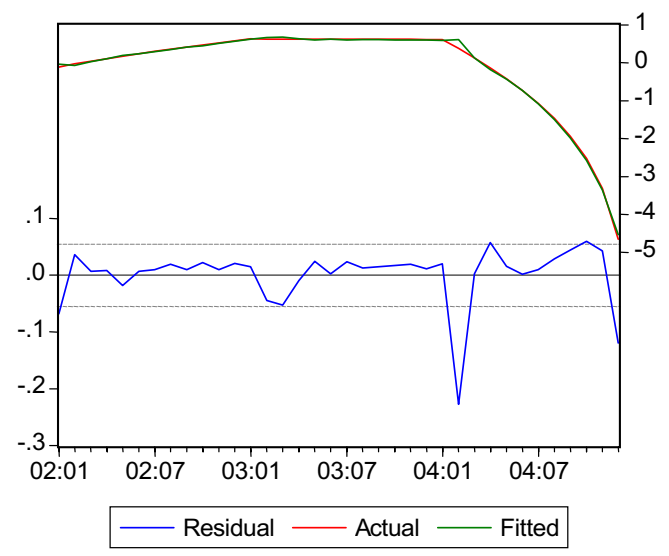


Figure 3

Actual, Fitted and Residual Values for the Czech Republic from 1996:02 to 2000:08

Picture 3: Actual, Fitted and Residual Values for the Czech Republic from 1996:02 to 2000:08

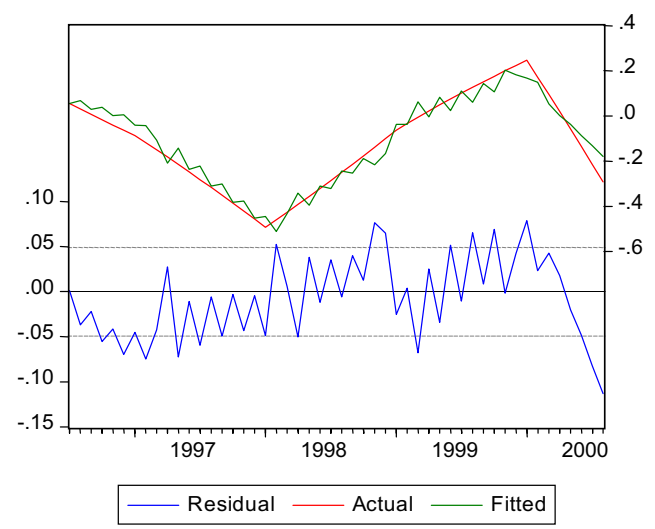

Figure 4

Actual, Fitted and Residual Values for the Czech Republic from 2000:09 to 2004:12

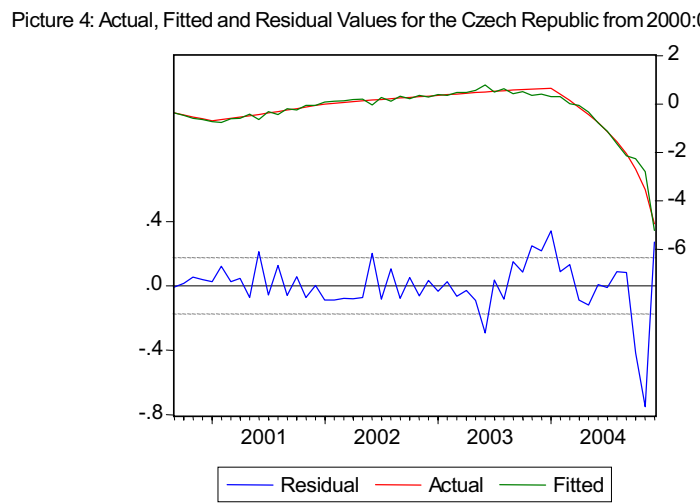


Figure 5

Actual, Fitted and Residual Values from 1997:08 to 2004:12 for Hungary

Picture 5: Actual, Fitted and Residual Values from 1997:08 to 2004:12 for Hungary

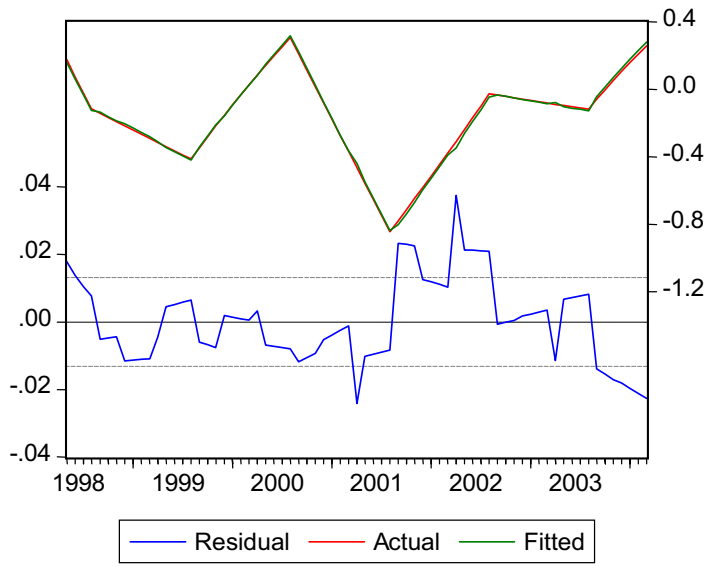

Figure 6

Actual, Fitted and Residual Values for Poland from 1999:02 to 2004:12

Picture 7: Actual, Fitted and Residual Values for Poland from 1999:02 to 2004:12

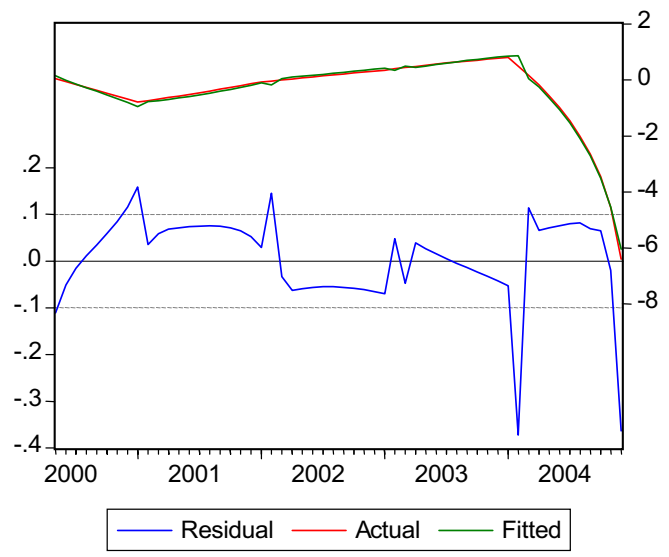


Figure 7

Actual, Fitted and Residual Values for Slovakia 1997:02 to 2004:12

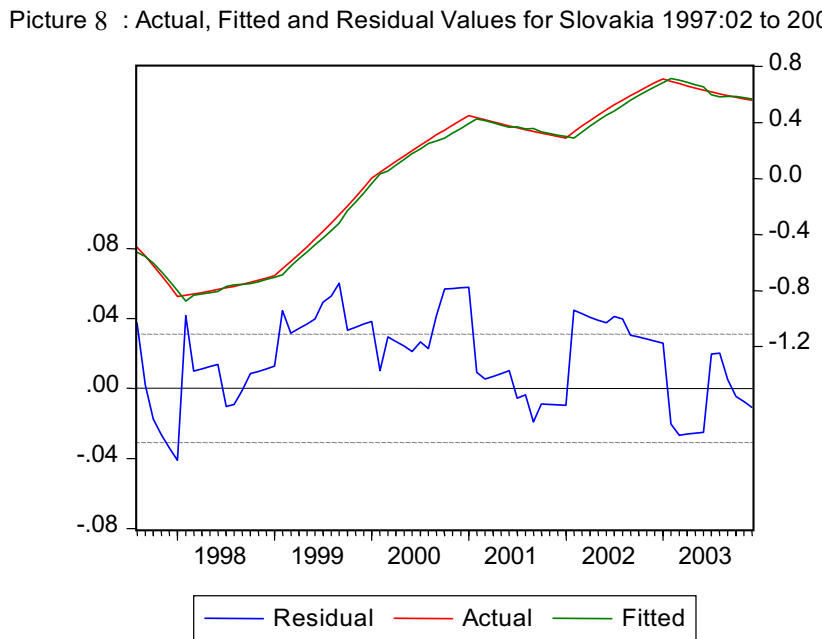

\section{References}

Abel, B.A. (1988), "Stock Prices Under Time-Varying Dividend Risk: an Exact Solution in an Infinite-Horizon Equilibrium Model." Journal of Monetary Economics, 22(3), November, pp. 375-393.

Amato D.J., Craig H.F. (2003), “Are Credit Ratings Procyclical?” Basel: BIS Working Papers No. 129, pp. 8-12. http://www.bis.org/publ/work129.pdf.

Bangia, A., Diebold, F.X., Kronimus, A., Schagen, Ch., Schuermann, T. (2002), "Ratings Migration and the Business Cycle with Application of Credit Portfolio Stress Testing." Journal of Banking and Finance, 26(3), pp. 445-474.

Barsky, B.R. (1989), "Why Don't the Prices of Stocks and Bonds Move Together? American Economic Review 79(5), pp. 1132-1145.

Barsky, B. R., De Long, B.J. (1993), "Why Does the Stock Market Fluctuate?" Quarterly Journal of Economics, 108(2), Mai, pp. 291-311.

Beloglavec, S. (2004), "Nove bančne storitve z vidika izboljšave poslovnih procesov in zadovoljstva komitenta" [New Banking Services from the Point of View of the Satisfaction of Bank Commitments]. Maribor: Faculty of Business and Economics, Masters Degree, p. 160.

Bernanke, B. (1983), "Nonmonetary Effects of the Financial Crisis in Propagation of the Great Depression." American Economic Review, 73(3), pp. 257-76.

Bernanke, B., Gertler, M. (1989), "Agency Costs, Net Worth and Business Fluctuations." American Economic Review, 79(1), pp. 14-31.

Bernanke, B., Gertler, M. (1995), "Inside the Black Box: the Credit Channel of Monetary Policy Transmission." Journal of Economic Perspectives, 9(4), Fall, pp. 27-48.

Bernanke, B., Gertler, M. (1999), "Monetary Policy and Asset Price Volatility." Federal Reserve Bank of Kansas City Economic Review, 84(4), pp. 17-51.

Bernanke, B., Gertler, M., Gilchrist, S. (1999), "The Financial Accelerator in a Quantitative Business Cycle Framework," in Taylor, J.B., Woodford, M.(eds), Handbook of Macroeconomics. Elsevier Science, North-Holland, Handbooks in Economics, Vol. 15, pp. 1341-1393. 
BIS (2004), "Basel Committee on Banking Supervison", in International Convergence of Capital Measurement and Capital Standards. Bank for International Settlements, July, pp. 14-36. http.// www.bis.org.

BIS (2005), "Bank Restructuring in Practice." BIS Policy Papers No. 6, August, pp. 25-34. http.// www.bis.org.

BIS (2005), "The $75^{\text {th }}$ Annual Report." Bank for International Settlements, June, pp. 41-63. http:// www.bis.org.

Borio, C., Claude, E., Lowe, P. (2002), "Asset Prices, Financial and Monetary Stability: Exploring the Nexus." Bank for International Settlements, BIS Working Papers, No 114, July, pp. 3-45.

Borio, C., Furfine, C., Lowe, P. (2001), "Procyclicality of the Financial System and Financial Stability: Issues and Policy Options", in Marrying the Macro and Micro-Prudential Dimension of Financial Stability. Bank for International Settlements, March, No. 1, pp. 24-31. http.// www.bis.org.

Boršič, D. (2005), "Exchange Rates in Some New EU Member States." Bančni vestnitk, 54(11), November, pp. 9-14.

Brennan, M., Yihong Xia (2001), Stock Prices Volatility, Learning and the Equity Premium. Los Angeles: Anderson Graduate Scholl of Management, University of California. http://repositories.collib.org/anderson/fin/19-01org/anderson/fin.

Calomiris, Ch. (1995), "Financial Fragility: Issues and Policy Implications." Journal of Financial Services Research, 9(3-4), December, pp. 241-57.

Canova, F., Pina, J. (1998), "Monetary Policy Misspecification in VAR Models.” Basel: Bank for International Settlements, CEPR.

Cecchetti, S., Genberg, H., Lipsky, J., Wadhwani, S. (2000), "Asset Prices and Central Bank Policy. London: International Center for Monetary and Banking Studies, pp. 42-56.

Charemza, W.W, Deadman, D.F. (1997), New Directions in Econometric Practice. Cheltenham: Edward Elgar, pp. 176-179, 190-192, 228-230.

Chen, Nan-Kuang (2001), "Bank Net Worth, Asset Prices and Economic Activity." Journal of Monetary Economics, 48(2), 2001, pp. 415-436.

Chen, Y.P., Popovich, P.M. (2002), "Correlation: Parametric and Nonparametric Measures", in Series Quantitative Applications in the Social Series. CA Thousand Oaks, Sage University Publications, Paper No. 139, pp. 13-45.

Crouhy, M., Galai, D., Mark, R. (2000), "A Comparative Analysis of Credit Risk Models." Journal of Banking and Finance, 24(1-2), pp. 57-117.

Davis, E.P. (1999), Financial Data Needs for Macro-Prudential Surveillance: What Are the Key Indicators of Risks to Domestic Financial Stability? London: Bank of England, Centre for Central Banking Studies, 2, 2, May, pp. 8-15.

Diamond, D., Dybvig, P. (1983), "Bank Runs, Deposit Insurance and Liquidity." Journal of Political Economy, 91(3), pp. 401-19.

Diamond, D., Rajan, R.G. (2001), "Liquidity Risk, Liquidity Creation and Financial Fragility: a Theory of Banking." Journal of Political Economy, 109(2), pp. 287-327.

Dickey, A.D., Fuller, W.A. (1979), "Distribution of the Estimators for Autoregressive Time Series with Unit Root." Journal of American Statistical Association, 74, June, pp. 427-431.

ECB (2001), "Capital Volatility and Pro-Cyclicality in the New Accord." Credit Suisse First Boston, European Central Bank, pp. 13-19. http://www.ecb.int.

ECB (2005), "Banking Structures in the New EU Member States." European Central Bank, January Report, pp. 9-16, 15-28, 32-41. http://www.ecb.int.

Eichenbaum, M. (1992), "Comment on Interpreting the Macroeconomic Time Series Facts: The Effects of Monetary Policy." European Economic Review, 24(6), pp. 310-331.

Engle, F.R., Granger, C.W.J. (1978), "Co-Integration and Error Correction Representation Estimation and Testing." Econometrica 46(2), pp. 251-276. 
Englund, P. (1999), "The Swedish Banking Crisis: Roots and Consequences." Oxford Review of Economic Policy, 15(3), pp. 80-97.

European Commission (2004), "Convergence Report." Brussels: European Commission. http:// europa.eu.int/scadplus/leg/en/lvb/l25057.htm.

European Commission (2004a), "Commission Recommendation on the 2004 Update of Broad Guidelines of the Economic Policies of the Member States and the Community - for the Period 2003-2005." Brussels: European Commission. http://europa.eu.int/scadplus/leg/en/lvb/ I25078.htm.

European Commission (2005), "Convergence Report." Brussels: European Commission, Autumn Forecast. http://europa.eu.int/scadplus/leg/en/lvb/l25057.htm.

Eurostat (2005), "Economy and Finance Data." http://epp.eurostat.cec.eu.int/portal.

Eviews 4.0 Instructions (2003), "Econometric Program for Windows and Macintosh." Irvine, CA: QMS - Quantitative Micro Software, pp. 166, 213, 260, 297-303, 257-260, 312-324, 364-366, 489-498, 504-511, 519-520.

Fisher, I. (1933), „The Debt-Deflation Theory of Great Depressions.“ Econometrica, 1(4), October, pp. 337-57.

Friedman, M., Schwartz, A. (1963), A Monetary History of the United States, 1867-1960. Princeton: Princeton University Press.

Fry, M. (1997), Emancipating the Banking System and Developing Markets for Government Debt. London, Routledge, Bank of England, Centre for Central Banking Studies, pp. 37-49.

Frye, J. (2000), "Depressing Recoveries." Chicago: Federal Reserve Bank of Chicago, Emerging Issues Series, S\&R, October, No. 8, pp. 3-14.

Fuller, A.W. (1976), The Introduction to Statistical Time Series. New York: John Willey and Sons, pp. 78-81.

Gerard, C., Klingebiel, D. (2003), "Episodes of Systemic and Borderline Financial Crises 1970s2002." World Bank. http://econ.worldbank.org/programs/finance/datasets.

Gertlei, R.M., Aiyagari, R.S. (1999), "Overreaction of Assets Prices in General Equilibrium." Review of Economic Dynamics, 16(2), 3-35. http://www.idealibrary.com on.

Gertler, M., Goodfried, M., Issing, O., Spaventa, L. (1998), "Asset Prices and Monetary Policy: Four Views." Basel: Bank for International Settlements, CEPR, pp. 5-14.

von Goetz, P. (2004), "Asset Prices and Banking Distress: a Macroeconomic Approach." Basel: BIS Working Paper, No. 167, pp. 23-26.

Golin, J. (2005), The Bank Credit Analysis Handbook, a Guide for Analysts, Bankers and Investors. London: Wiley Finance.

Goodhart, Ch., Danielsson, J. (2001), "The Inter-Temporal Nature of Risk”, in Société Universitaire Européanne Recherches Financiéres. 23rd SUERF Colloquium on Technology and Finance: Challenges for Financial Markets, Business Strategies and Policymakers. Brussels, October, pp. 26-59.

Gordy, B.M. (2000), “A Comparative Anatomy of Credit Risk Models.” Journal of Banking and Finance, 24, January, pp. 199-249.

Grossman, J.S., Shiller, R.J. (1981), "The Determinants of the Variability of Stock Market Prices." American Economic Review, 71(2), Mai, pp. 222-227.

Hamilton, D.J. (1994), Time Series Analysis. New York: Princeton University Press, pp. 53-69.

Hansen, J. (2003), "Financial Cycles and Bankruptcies in the Nordic Countries." Stockholm: Central Bank of Sweden, Sveriges Riksbank, Working Paper Series, No 149. http:// www.riskbank.com/templates/Document.aspx?id=8230.

Hauptman, L. (2004), "Skupinska obdavčitev »Group taxation«", in Turk, I. (ed.), Publication from the Conference, Ljubljana, Slovenian Institute for Revision, pp. 61-83.

Hong, Y. (2001), Estimating Uncertainty and the Equity Premium. Austin: Texas University, pp. 87114. HYPERLINK „http://www.mccombs.utexas.edu/faculty/hong.yan/research/EP1.pdf“ http:// www.mccombs.utexas.edu/faculty/hong.yan/research/EP1.pdf.. 
Hoshi, T., Kashyap, A. (1999), "The Japanese Banking Crisis: Where Did it come From and How Will It End?" National Bureau of Economic Research, Macroeconomics Annual, pp. 129-201. http://www.ideas.repec.org/p/nbr/nberwo/7250.html.

Issing, O. (2005), "The Monetary Pillar of the ECB." Revised Paper Initially Prepared for the Conference on the ECB and Its Watchers. Financial Stability Review, VII(3), June. http:www.ecb.int/press/key/date/2005/html.sp050531.en.html.

Jordan, J., Peek, J., Rosengren, E. (2002), "Credit Risk Modelling and the Cyclicality of Capital," in Federal Reserve Bank of Boston. Changes in Risk through Time, Measurement and Policy Options, March. http://www.bis.org/events/conf020306.htm.

Kiyotaki, N., Moore, J. (1997), "Credit Cycles." Journal of Political Economy, 105(2), pp. 211-48.

Lopez, A.J. (2002), "The Relation Between Average Asset Correlation, Firm Probability of Default and Asset Size," in Conference on Economic Assessment. Basel: BIS, pp. 18-23. http:// www.bis.org.

Mehra, R., Prescott, E.C. (1985), "The Equity Premium: a Puzzle." Journal of Monetary Economics, 15(2), March, pp. 145-161.

Mishkin, F., White, E. (2003), "U.S. Stock Market Crashes and Their Aftermath: Implications for Monetary Policy", in Hunter et al. (eds.), Effects on Monetary Policy, NBER, Working Papers No. 8992, Chapter 6. http://ideas.perec.org/p/hut/ruters/200208.html.

Mishkin, S.F. (1999), "Global Financial Instability: Framework, Events, Issues." Journal of Economic Perspectives, 13, Fall, pp. 3-20.

Mlinarič, F. (2000), "Ali bo zakon o finančnem poslovanju podjetij res opravil s finančno nedisciplino?" [Financial Law and Its Possibilities For Improving Financial Discipline]. Review For Revision and Finance, 27(6), pp. 15-37.

Moody's (2005), "Ratings Performance 2004," Special Report. http://www.moodys.com.

Oplotnik, J.Ž. (2003), "Capital Flows Adjustment in Slovenia: Assessment of Design and Efficiency." Post-Communist Economies, 15(2), pp. 209-225.

Rajan, G.R. (2005), "Has Financial Development Made the World Riskier?" Paper Presented at the Jackson Hole Conference, August. http://neweconomist.blogs.com/new_economist/2005/ papers_from_the-html.

Ramsey, B.J. (1969), "Test for Specification Error in Classical Linear Least Squares Residuals Regression Analysis." Journal of Royal Statistical Studies 31(2), pp. 350-371.

Rostowski, J. (2005), "How to Reform the Stability and Growth Pact," in Dabrowski, M., Rostowski, J. (eds.), The Eastern Enlargement of the Eurozone. Boston: Kluwer Academic Publishers, pp. 185-198.

Rubinfeld, L.D., Pindyck, R.S. (1991), Econometric Models and Economic Forecasting. New York, McGraw-Hill, International editions, pp. 250-252.

Sargent, J.T. (1981), "Interpreting Economic Time Series." Journal of Political Economy 89(2), pp. 213-248.

Saunders, A., Allen, L. (2003), "A Survey of Cyclical Effects in Credit Risk Measurement Models." Basel: BIS, Working Paper No. 126, January, pp. 19-26.

Sigbjørn, B. (1998), "Bank Failures in Scandinavia", in Caprio et al. (eds.), Preventing Bank Crises - Lessons from Recent Global Bank Failures, Chapter 11. Washington: World Bank, pp. 57-88.

Timmerman, A. (1996), "Excess Volatility and Predictability of Stock Prices in Autoregressive Dividend Models with Learning." Review of Economic Studies, 63(4), pp. 523-557.

Veronesi, P. (2000), "How Does Information Quality Affect Stock Returns?" Journal of Finance, 55(6), pp. 807-837.

Vihriala, V. (1997), "Banks and the Finnish Credit Cycle 1986-1995." Central Bank of Finland Research Department, Bank of Finland Studies E:7, pp. 26-33.

Wall, E.M., Rechtsteinerk A., Rocha, L.M. (2003), "Singular Value Decomposition and Principal Component Analysis," in Practical Approach to Microarray Data Analysis. Kluwer, Norwell, pp. 22-24. http://public.lanl.gov/mewall/kluwer2002.html. 
Weill, L. (2005), "On the Relationship between Competition and Efficiency in the EU Banking Sector." Kredit und Kapital, 37(3), pp. 329-332.

White, R.W. (2006), "Procyclicality in the Financial System: Do We Need a New Macrofinancial Stabilisation Framework?" Basel, BIS, Working Paper No. 193, January, pp. 6-24.

White, R.W. (2004), "Are Changes in FInancial Structure Extending Safety Nets?" Bank For International Settlements, BIS Working Papers No. 145, January, pp. 14-19.

\section{Data:}

http://dsbb.imf.org/Applications/web/sddsnsdppage

http://www.cnb.cz/en/statistics/sdds/

http://www.lbank.It/Eng/Statistics/nsdplt.htm

http://www.ksh.hu/pls/ksh/docs/eng/imf/nsdp.html http://www.stat.gov.pl/english/sdds/dane.htm http://www.statistics.sk/webdata/mmf/nssu.html

http://www.bsi.si/imf/ http://www.statistischedaten.de/ISAPI/DBDemo.dll/Sour-

ces?DB=EU\&File=EU\&Txt=Eurostat+Statistics

http://www.statistischedaten.de/ISAPI/DBDemo.dll/Sour-

ces?DB=WELT\&File=WELT\&Text=World+Statistics 